\title{
Discrete element modeling of a subduction zone with a seafloor irregularity and its impact on the seismic cycle
}

Liqing Jiao ${ }^{1,2}$, Chung-Han Chan ${ }^{3,4^{*}}$, Luc Scholtès ${ }^{5}$, Aurélia Hubert-Ferrari ${ }^{6}$, Frédéric-Victor Donzé ${ }^{7}$, Paul Tapponnier $^{8}$

$5 \quad{ }^{1}$ Institut de Physique du Globe de Paris, CNRS, Paris, France

${ }^{2}$ Université de Paris, Paris, France

${ }^{3}$ Department of Earth Science, National Central University, Taiwan

${ }^{4}$ Earth Observatory of Singapore, Nanyang Technological University, Singapore

${ }^{5}$ Université de Lorraine, CNRS, Laboratoire GeoRessources, Nancy, France

$10 \quad{ }^{6}$ Université de Liege, Department de Geography, Liege, Belgium

${ }^{7}$ Université Grenoble Alpes, Institut des Sciences de la Terre, Grenoble, France

${ }^{8}$ Institute of Crustal Dynamics, China Earthquake Administration, Beijing, China

Correspondence to: Chung-Han Chan (hantijun@googlemail.com)

Abstract. Seafloor irregularities influence rupture behavior along the subducting slab and in the overriding plate, thus affecting

15 earthquake cycles. Whether seafloor irregularities increase the likelihood of large earthquakes in a subduction zone remains contested, partially due to focus put either on fault development or on rupture pattern. Here, we simulate a subducting slab with a seafloor irregularity and the resulting deformation pattern of the overriding plate using the discrete element method. Our simulations illustrate the rupture along three major fault systems: megathrust, splay and backthrust faults. Our results show different rupture dimensions of earthquake events varying from tens to ca. $140 \mathrm{~km}$. Our results suggest that the recurrence

20 interval of megathrust events with rupture length of ca. $100 \mathrm{~km}$ is ca. 140 years, which is overall comparable to the paleoseismic records at the Mentawai area of the Sumatran zone. We further propose the coseismic slip amounts decrease and interseismic slip amounts increase from the surface downwards gradually. We conclude that the presence of seafloor irregularities significantly affects rupture events along the slab as well as fault patterns in the overriding plate.

25 Short summary. Seafloor geometry plays an important role in earthquake behaviors in a tectonic subducting system. Here, we simulate a subducting slab with a seafloor irregularity to perform the resulting deformation pattern of the overriding plate and spatial and temporal patterns of the seismicity activity in the subducting system. Our model is overall comparable to paleoseismic records, matches seismicity patterns, and fulfils the domain definition of a subduction system. 
https://doi.org/10.5194/se-2020-41

Preprint. Discussion started: 7 April 2020

(c) Author(s) 2020. CC BY 4.0 License.

(c) (i)

30

Seafloor irregularities are ubiquitous in subduction systems. They include seamounts, seamount chains, marine ridges, or oceanic plateaus with overall heights up to 6-7 km (e.g. Lallemand et al., 1992; Wang and Bilek, 2011, 2014), positioned between perpendicular to parallel to the trench (e.g., the Kyushu-Palau Ridge in the Nankai zone and the Cocos Ridge in the Costa Rica zone are at ca. $90^{\circ}$; the Nazca Ridge in the Peru subduction zone and the Louisville Ridge at the Tonga Trench are at ca. $45^{\circ}$; the Zenisu ridge is about parallel to the Nankai trench and Loyalty Ridge is also almost parallel to the New Hebrides Trench). Since the decapitation of these irregularities during subduction is extremely difficult (Wang and Bilek, 2011), the role of seafloor irregularities on seismic activity in subduction zones remains mostly controversial.

For instance, Singh et al. (2011) conducted a deep seismic reflection survey in Mentawai offshore of the Sumatran subduction zone (Fig. 1a), and identified a seamount (irregularity) of 3-4 km height and $40 \mathrm{~km}$ width, which has been subducted to the depth of 30-40 km (Fig. 1b). According to the spatial pattern of seismicity, Singh et al. (2011) suggested that the presence of the seamount reduces the possibility of megathrust earthquakes in this zone. On the other hand, the paleoseismic records (Fig. 1c) of relative sea-level change from coral data in the same area imply that there could be megathrust events with magnitudes of up to 8.8. Moreover, the data covering 700 years of events shows that this area actually ruptures cyclically roughly every 45200 years (Fig. 1c) (Sieh et al., 2008). The rupture pattern suggests that the next megathrust earthquake will probably take place within the next several decades, a potentially devastating event for the coastal region of central Sumatra. Thus, one line of evidence suggests the likelihood of megathrust events, whereas another downplays that possibility.

The role played by subducting slab irregularities was partly addressed by analyzing fault patterns in the overriding plate, and

50 particularly, fault generation and propagation (Dominguez et al., 1998a; Dominguez et al., 1998b; Dominguez et al., 2000), stress field disturbance (Ruh, 2016; Ruh et al., 2016), stress weakening as a function of the seamount dimensions (Ding and Lin, 2016), and fault pattern and décollement caused by seamount-forearc collision (Morgan and Bangs, 2017). Although some approaches can model earthquake ruptures along the slab (e.g., Scholz and Small, 1997; Yang et al., 2012, 2013; Yu et al., 2018), modeling of the associated fault patterns in the overriding plate as well as the slip rupture behavior along the slab have

55 not been achieved yet.

In this study, we use numerical experiments to study both fault generation and slip rupture behavior in a subduction zone. More specifically, we apply the approach to the Sumatran subduction zone where a seafloor irregularity is present on the subducting slab (Singh et al., 2011) in order to analyze the earthquake recurrence interval and rupture dimension along the 60 megathrust interface. We systematically compare our numerical results with seismic observations, seismic profiles, and paleoseismic records. We also discuss the deformation and fault structure of the overriding plate when subjected to subduction 
https://doi.org/10.5194/se-2020-41

Preprint. Discussion started: 7 April 2020

(c) Author(s) 2020. CC BY 4.0 License.

(c) (i)

considering slip accumulation, rupture recurrence as well as instantaneous velocity fields. Finally, we show that the presence of the seamount irregularity could be the source of a seismic cycle in the Sumatran subduction zone.

\section{Methodology}

65 To investigate the effect of a seafloor irregularity (e.g. seamount) on the behavior of a subduction zone and on rupture events, we performed numerical simulations based on the Discrete Element Method (DEM).

The DEM, initially proposed by Cundall and Strack (1979), has been successfully applied to simulate complex tectonics processes like, e.g., growth of fault-bends or fault-propagation folds (e.g., Benesh et al., 2007; Hughes et al., 2014), fold-

70 associated cracking (Finch et al., 2003, 2004; Hardy and Finch, 2005, 2006), graben generation (e.g., Seyferth and Henk, 2006), and shear and thrust faulting (Cardozo et al., 2005; Dean et al., 2013; Fournier and Morgan, 2012; Gray et al., 2014; Guo and Morgan, 2007, 2008; Guo and Morgan, 2004, 2006; Morgan, 1999, 2004, 2006; Morgan and Boettcher, 1999; Morgan and McGovern, 2005a, b; Oakley et al., 2007; Waltz et al., 2014; Zhang et al., 2013). The DEM has also been used to simulate thrust ramp formation and to determine the location of seismic events based on the velocity field within an accretionary wedge

75 (e.g., Strayer and Suppe, 2002), and to investigate the strength of faults, fault patterns, and earthquake magnitudes based on the length of fault ruptures (e.g., Strayer et al., 2010a; Strayer et al., 2010b).

In this study, we simulate the deformation of the overriding plate as well as the interface behavior between the overriding plate and the subducting slab of the Sumatran subduction zone by adapting the model proposed by Jiao et al. (2018). The model was

80 implemented in the Yade DEM software (see Kozicki and Donzé, 2008, 2009; Šmilauer, 2015 for details), whose flexibility allowed us to define a specific model relevant to study both faulting and slip along faults.

\subsection{Model formulation}

As in every DEM model, the medium is discretized as an assembly of rigid particles interacting through specific interaction

85 laws. The medium as a whole can deform and fracture based on the elastic-plastic behaviors described by these interaction laws. The overall behavior of the material is governed by the motion of its constitutive particles ruled by Newton's second law. The computing cycle can be decomposed into four main steps related, respectively, to (1) the determination of the positions of the constitutive elements, (2) the determination of their potential interaction, (3) the computation of the forces applied to each of them according to the predefined interaction laws, and (4) the calculation of their updated positions through

90 the integration of the equations of motion. The calculation cycle is repeated iteratively until the simulation stops. Because of the dynamic formulation of the method (explicit time-domain integration), a non-viscous damping is used to dissipate kinetic energy and facilitate convergence towards quasi-static equilibrium. This damping directly acts on the interaction forces before 
https://doi.org/10.5194/se-2020-41

Preprint. Discussion started: 7 April 2020

(c) Author(s) 2020. CC BY 4.0 License.

(c) (i)

their numerical integration in the equations of motion, so that the displacements are calculated from the damped forces. This is a convenient numerical tool to ensure the convergence of the simulations (see Duriez et al., 2016 for details), but it needs to be used with caution to prevent any bias.

The inter-particle behavior of our DEM model can be decomposed into the normal and tangential directions of the contact plane. The normal contact model accounts for both divergence and convergence (Fig. 2).

100 In the convergence regime (compression of the contact/bond), the normal force $F_{n}$ is computed as:

$$
F_{n}=K_{n} \cdot U_{n},
$$

where $U_{n}$ is the normal component of the relative displacement between particles A and B, and $K_{n}$ the normal stiffness derived from the properties assigned to the particles, such that:

$$
K_{n}=\frac{2 \cdot E_{A} \cdot R_{A} \cdot E_{B} \cdot R_{B}}{E_{A} \cdot R_{A}+E_{B} \cdot R_{B}},
$$

where $R_{A}$ and $R_{B}$ are the radii of the particles and $E_{A}$ and $E_{B}$, their respective elastic moduli, are directly related to the bulk modulus of the simulated medium.

In the divergence regime (extension of the contact/bond), the normal force is computed with the same stiffness as that defined for the convergence regime. The inter-particle distance can increase up to $U_{n}^{\text {tensile }}$, for which the maximum admissible tensile 110 force $F_{n}^{\max }$ is reached:

$$
F_{n}^{\max }=t \cdot A_{\text {int }},
$$

with $t$ the tensile strength of the interparticle bond and $A_{\text {int }}=\pi \cdot\left(\min \left(R_{A}, R_{B}\right)\right)^{2}$ the interacting surface area between $\mathrm{A}$ and B. When $F_{n}^{\max }$ is reached, the force is not set to zero immediately as it is usually for modeling brittle rocks (e.g. Scholtès and Donzé, 2013). Instead, $F_{n}$ gradually decreases, describing a softening behavior at the particle scale between $U_{n}^{\text {tensile }}<U_{n}<$ $115 U_{n}^{\text {rupture }}$, according to:

$$
F_{n}=F_{n}^{\max }-\frac{K_{n}}{S}\left(U_{n}-U_{n}^{\text {tensile }}\right)
$$

where $s$ is a weakening coefficient that needs to be defined. If the inter-particle distance continues to increase, the inter-particle bond breaks when $U_{n}>U_{n}^{\text {rupture }}$ and all forces are set to zero. A crack is then defined at the location of the bond breakage. 
https://doi.org/10.5194/se-2020-41

Preprint. Discussion started: 7 April 2020

(c) Author(s) 2020. CC BY 4.0 License.

(c) (i)

120 As in classic DEM formulations (Hart et al., 1988), the tangential force $F_{S}$ at the current time step $t$ is computed incrementally as:

$$
F_{s}^{(t)}=F_{s}^{(t-\Delta t)}+K_{s} \cdot \Delta U_{s}
$$

with $F_{s}^{(t-\Delta t)}$ the force computed at the previous time step, $\Delta U_{s}$ the incremental tangential displacement between $\mathrm{A}$ and $\mathrm{B}$, and $K_{s}$ the tangential stiffness, defined as $K_{S}=a \cdot K_{n}$ with $a$, a coefficient related to the Poisson's ratio of the simulated medium.

As for the normal force, a maximum admissible tangential force $F_{s}^{\max }$ is defined as:

$$
F_{s}^{\max }=c \cdot A_{\text {int }},
$$

with $c$ the inter-particle cohesion (Fig. 2). Once the tangential force reaches this limit, the tangential force stays equal to its maximum value until the maximum admissible normal force is reached.

130

One crucial aspect of the model is that, unlike in classic DEM approaches where particles behave in a purely frictional way once the interparticles bonds have broken, every new detected contact are set as cohesive bonds (Fig. 3). These bonds have the same strength as the initial ones. This procedure provides a way to model the healing processes that eventually take place along faults. Since healed contacts are generally located in localized areas, they tend to weaken the bonds in these areas (e.g., fault zones). This healing procedure also permits to control the dilatancy of the medium undergoing failure.

\subsection{Model setup}

\subsubsection{Geometry and boundary conditions}

To address the influence of a seamount on the rupture behavior along a subducting slab, we set up a 2D model corresponding

140 to a cross section perpendicular to a trench. We defined the numerical model geometry based on the Sumatran subduction zone depicted by Singh et al. (2011). The numerical set up is shown in Fig. 4. The overriding plate is set up as a 50-km deep and 230-km wide wedge. The seamount (39 km wide, $6 \mathrm{~km}$ high) is located $30 \mathrm{~km}$ below the top of the overriding wedge and 160 $\mathrm{km}$ away from the trench, similarly to what could be observed for the subduction slab in Mentawai. The rigid slab is $10 \mathrm{~km}$ thick, a general thickness for oceanic slabs (Hayes et al., 2012). 
https://doi.org/10.5194/se-2020-41

Preprint. Discussion started: 7 April 2020

(c) Author(s) 2020. CC BY 4.0 License.

(c) (i)

All these components were filled in with spherical discrete elements. The mean radius of the elements is ca. $1 \mathrm{~km}$ and the porosity of the model is ca. 0.64 . The seamount and the slab were modeled as rigid media moving together as one. The subduction rate was set to $6 \mathrm{~cm} /$ year horizontally and to $1.2 \mathrm{~cm} /$ year vertically (Singh et al., 2011). The right boundary of the overriding plate is fixed while the slab continuously subducts, which compares to the creeping patch related to the subducting slab.

\subsubsection{Model scaling}

We scaled the elastic and strength properties of the model in order to simulate the rupture/seismic cycle behavior in subduction zones.

In order to understand the stress-strain relationship of the material in the overriding plate, the model's parameters were chosen in Table 1, so that the numerical medium shows the elasto-plastic behavior (Supplementary Fig. S1). Such behavior enables to simulate nucleation and propagation of faults associated to strain softening as well as sliding along faults in the residual state.

To scale the deformation properties, we weaken the elastic properties. We chose elastic stiffnesses one thousandth of the natural stiffness, so that the elastic strain limit of the numerical medium is ca. $10 \%$. In nature, the elastic strain limit of rock (e.g., granite) is ca. $0.01 \%$ (e.g., Okubo and Fukui, 1996). Thus, considering the resolution limit of the model, we set that a 1$\mathrm{km}$ deformation in the model is scaled down to a 1-m deformation in nature.

To scale the strength properties, we followed the classical scaling law (Hubbert, 1937, 1951; Peltzer, 1988). If $\sigma_{c}$ represents the average strength of the lithosphere, its thickness is $h_{c}$, the gravitational acceleration is $g_{c}$ and its density is $\rho_{c}$, the dimensionless force ratio $\frac{F_{t}}{F_{g}}=\frac{\sigma_{c}}{\rho_{c^{\prime}} g_{c^{\prime}} h_{c}}$ expresses the balance between the tectonic forces $F_{t}$ and the gravity induced forces $F_{g}$. If the value of this ratio is similar in nature and in the numerical model, the model is scaled with respect to gravity.

For the continental lithosphere, considering $\sigma_{c}=5 * 10^{5} \mathrm{kPa}, h_{c}=10^{5} \mathrm{~m}, \rho_{c}=2.8 \mathrm{~g} / \mathrm{cm}^{3}$, and $g_{c}=9.8 \mathrm{~m} / \mathrm{s}^{2}, \frac{F_{t}}{F_{g}}=0.17$.

On the other hand, we use $\sigma_{c}{ }^{\prime}=180 \mathrm{kPa}, h_{c}{ }^{\prime}=50 \mathrm{~km}, \rho_{c}{ }^{\prime}=2.7 \mathrm{~g} / \mathrm{cm}^{3}$, and $g_{c}{ }^{\prime}=10 \mathrm{~m} / \mathrm{s}^{2}$ in our model, and then we obtain $\frac{F_{t}{ }^{\prime}}{F_{g}{ }^{\prime}}=0.13$, similar with 0.17 obtained for the real continent. The strength of the model is from the uniaxial test (Supplementary Fig. S1). 
https://doi.org/10.5194/se-2020-41

Preprint. Discussion started: 7 April 2020

(c) Author(s) 2020. CC BY 4.0 License.

(c) (i)

\subsubsection{Model calibration}

Before simulating the earthquake rupture behavior along the subduction zones, we calibrated our model by studying the stressstrain responses of the overriding plate and of the interface between the overriding plate and the slab, respectively (Fig. 5).

180 In order to understand the stress-strain relationship of the material in the overriding plate and of the interface between the overriding plate and slab, we extracted two subvolumes from the model (Fig. $5 \mathrm{a}$ and b) to perform shear tests. The square block was used to characterize the plate behavior (Fig. $5 \mathrm{a}$ and c) while the purple block and white slab were used to characterize the megathrust fault behavior (Fig. $5 \mathrm{~b}$ and d). The stress-strain responses and associated deformation fields obtained from both cases, which indicate the stress accumulation and release behavior along the faults (Fig. 5 e and f). These tests confirm

185 that this model is able to simulate the fault generation inside the overriding plate and the stress accumulation-and-release behavior along the generated or pre-existing faults. We use this model to simulate the rupture/seismic behavior (also stress accumulation-and-release behavior) of the megathrust fault (pre-existing fault) and the possible splay fault (generated fault) in the Sumatran subduction zone.

\subsubsection{Preconditioning}

Before simulating the rupture behavior of the subduction zone, the model needed to be preconditioned. The initial state of stress (Fig. 6) is generated by first letting the prism stabilize under gravity and then, second, by moving the subducting slab until the occurrence of the first megathrust event which occurred after ca. 200 years of deformation in our model (Supplementary Fig. S2). This loading sequence corresponds to the first stick-slip sequence that induces a quasi-elastic rebound

195 of the overriding plate. We consider that the model is preconditioned right after the occurrence of this first rebound since further displacement of the subducting slab starts a new stick-slip sequence in the rupture cycle (seismic cycle) that leads to another rebound of the overriding plate. The rebound tends to reset the state of stress within the overriding plate. Thus, we record the deformation from this deformation stage, 200 years being the actual point of reference of time in our simulations.

200 This model enables us to investigate the earthquake cycle by estimating the frequency of large and small earthquakes as well as by characterizing the nucleation of splay faults caused by the subducting irregularity. The magnitudes of the events are scaled by their rupture length. In addition, we also analyzed the slip behavior occurring along the megathrust and splay faults during both coseismic and interseismic periods. 
https://doi.org/10.5194/se-2020-41

Preprint. Discussion started: 7 April 2020

(c) Author(s) 2020. CC BY 4.0 License.

(c) (i)

\section{Modeling results and discussions}

To investigate the earthquake recurrence interval and rupture dimension along the megathrust interface, we simulated the subduction process up to the point where the overriding plate travelled ca. $24.5 \mathrm{~m}$, corresponding to the duration of approximately 400 years. The final deformation is shown in Fig. 7. In the following, we analyze how much deformation occurred above the slab and how the overriding plate responded to the constant downward slab motion.

\subsection{Displacement field of the overriding plate}

We calculated the displacement of the overriding plate during the simulated 400 years (Fig. 8). We also tracked the areas where interparticle ruptures occurred (called cracks hereafter) so as to identify fault zones (Fig. 8). After the seamount moved with the slab by ca. $24.5 \mathrm{~m}$ (Fig. 8), the cracks concentrated on three main regions: one along the interface between the slab and the overriding plate (the megathrust fault), and the other two on each side of the seamount; a front thrust fault (also called Splay Thrust, ST) that developed from the landward flank of the seamount; and a Back Thrust (BT) that originated from the landward base of the seamount. The cracked areas corresponding to these two fault zones are relatively wider than the one along the megathrust fault. The BT is actually thickened with several short conjugate faults visible on Fig. 8a and b.

Beside the crack swarms, the displacement field (Fig. 8a and b) is conspicuously separated by the ST and BT faults. The summit of the seamount divided the entire subducting interface into two patches. The shallow patch in the frontal accretionary prism is located at the seaward side of the model in front of the ST. This frontal accretionary prism suffered ca. $6 \mathrm{~m}$ of horizontal displacement with respect to the fixed boundary (Fig. 8a), and a maximal subsidence of ca. $2 \mathrm{~m}$ (Fig. 8b). The slab subducted for ca. $24 \mathrm{~m}$ during the 400 years. The movement of the upper plate was different from that of the slab because of the rupture events that occurred along the interface between the upper plate and the subducting slab. Due to the ruptures along the ST and the BT faults, the patch at the back of the prism suffered a ca. $3 \mathrm{~m}$ uplift (Fig. 8b) and a relatively small horizontal displacement (less than $1 \mathrm{~m}$ ) compared to that of the shallow patch (Fig. 8a).

Due to the splay fault (ST), which is related to the seamount, the deformation results show significant horizontal displacement 230 at shallow depths (frontal accretionary prism, seaward side of the model), while maximal subsidence can be observed along the splay fault (color fields in Fig. 8a and b). At greater depths (back of the prism, landward side of model), horizontal slip is small, while vertical displacements are significant due to ruptures that occurred along the splay fault and the backstop thrust.

In addition, in order to measure the vertical displacement along the subducting slab, we recorded the vertical motion of a series 235 of points P1-5 during the simulated 400 years (Fig. 8c). Three big events BE1-3 (vertical slip $>0.4 \mathrm{~m}$ during events at point P1 close to the trench) occurred in 272, 412, and 551 years, respectively, corresponding to a recurrence interval of $139.5 \pm 2.5$ 
https://doi.org/10.5194/se-2020-41

Preprint. Discussion started: 7 April 2020

(c) Author(s) 2020. CC BY 4.0 License.

$(\sim 140)$ years. Even though the experiment only run for 400 years, the occurrence of these big events clearly seems periodic. The displacement paths of P2 and P3 are similar to that of P1, but these two points, which are close to the splay fault ST, show smaller uplifts compared to P1 during the big events BE1-3. P4 and P5, which are located on the back prism, are not sensitive to the big events.

The vertical displacement record of P1 (Fig. 8c) shows different tendencies before and after the big events. Here, we consider the deformation before and during the big event BE1 (i.e., in one cycle) as an example. We define the time between 200 to 272 years as the period before BE1, since the vertical deformation of most part of the frontal prism (e.g., P1) in this period was mostly oriented downwards. We define the time between 272 to 280 years as the period during the BE1, since the vertical deformation of most part of the frontal prism in this period was mostly upwards (e.g. P1 in Fig. 8c). Before BE1, the frontal prism moved landwards (Fig. 9a) and downwards (Fig. 9b) with the slab. The back prism was raised by the splay fault (ST) and back thrust (BT), delineated by the crack swarms. During BE1, the frontal prism rebounded seawards (Fig. 9c) and upwards (Fig. 9d). The entire overriding plate seemed to behave elastically, and the seaward motion increased gradually from the back to the frontal prism. The overriding plate generally moved upwards, except for the zone located just above the seamount, which moved downwards, affected by the seamount. During this period, there was no slip along either the splay fault or the back thrust fault. In details, the vertical displacement records (Fig. 9e) also show that P1-3, both located in the frontal prism, generally moved downwards before BE1 and upwards during BE1. P5, located in the back prism, moved upwards before and during $\mathrm{BE} 1$, and $\mathrm{P} 4$, located in the back prism but above the seamount, moved upwards before BE1 and downwards during BE1. The similar behavior can be identified in the other cycles (e.g., detailed deformation before and during the last event BE3 can be referred in Supplementary Fig. S3).

\subsection{Slip accumulation along the slab}

In order to understand the slip cycle along the interface between the slab and overriding plate, we measured the slip deformation that occurred along the slab interface every 0.2 years (Fig. 10). The deformation corresponds here to the relative slip with respect to the slab and is thus different from the absolute displacement presented in Figs. 8 and 9. Hence, the elements close to the fixed boundary, located at the bottom-right corner of the upper plate, show a constant slip rate (i.e. homogeneous increasing slip amount along the vertical axis in Fig. 10a) with respect to the subduction slab. Apart from those elements at bottom-right corner of the upper plate, the ones located along the interface present various slip rate, implying stress concentration and release along the interface during the subduction process. We then identified the number of rupture events when the accumulated stress releases as well as their corresponding magnitude during the simulated period (400 years). Here, we only measured the slip along the interface as the slip along ST or BT can be interpreted through the displacement field inside the upper plate (Fig. 8 and 9). The accumulated slip spectrum (Fig. 10) along the slab also shows that ST separates the frontal and back prism parts. The deformation pattern is dominated by the three big events (BE1-3 in Fig. 10; first labeled in 
https://doi.org/10.5194/se-2020-41

Preprint. Discussion started: 7 April 2020

(c) Author(s) 2020. CC BY 4.0 License.

(c) (i)

270 Fig. 8) accompanied with smaller magnitude sub-events. The relative lighter areas (less density of gray lines) located in the frontal prism correspond to the large cumulated slip that developed during these big events. These ruptures propagated to the trench region, inducing deformation at the surface. Their rupture lengths along the slab interface were ca. $100 \mathrm{~km}$. The subevents, labeled SE (Fig. 10), only ruptured for ca. $50 \mathrm{~km}$. Some ruptures extended to the trench region (such as SE1-4), whereas some did not (such as SE5).

We analyzed the cumulated slip varying with the time and we displayed the cumulated slip along the slab in Fig. 10. Such slip history can be further discussed with respect to key reference locations (A to K) located in the corresponding figures.

For further analysis of the deformation process, the segment from points B to $\mathrm{G}$ was considered as the main frontal prism.

280 After BE1 and BE3, the accumulated slip amounts from point B to point G were very similar (sub horizontal line from B to $\mathrm{G}$ at the top of the lighter areas in Fig. 10). It suggests that these big events may have completely released the accumulated stress along the slab and may have ruptured the entire frontal prism from A to G along the slab. The seaward side of point B (ca. 25 $\mathrm{km}$ from the trench landwards) was affected by some shallow disturbances. After BE2, stresses were not yet totally released in some parts of the main frontal prism, so BE2 was followed by some smaller rupture events SE2-4, which appeared on the

285 segment close to the trench. During each event, the stresses in the frontal prism might be released partially. After these subevents, the accumulated slips of the main frontal prism were homogeneous distributed over time (the top of the lighter area was not horizontal after the event; Fig. 10). After decades of stress accumulation, the stresses were partially released first during the sub-event SE5, and then entirely released by the next big event BE3.

290 The cumulated horizontal slip (Fig. 10b) is similar to the accumulated resultant slip, associated with the big events BE1-3 and the sub-events SE1-5, but the cumulated slip distribution history of the back prism (from point H landwards) is slightly different from the resultant one. The cumulated vertical slip field (Fig. 10c) shows more details about the deformation processes for the frontal prism and in particular for the back prism. In the frontal prism, the three big events and five sub-events readily resulted in vertical slips (Fig. 10c) as well as in cumulated resultant slip (Fig. 10a). The back prism suffered much more vertical slip

295 than the frontal prism. The difference between the frontal and back prisms was in fact due to the slip along the splay fault. In addition, from the accumulated slip distribution in the back prism, we could identify smaller events, which ruptured the part from the seamount landwards.

\subsection{Slip velocity along the slab}

300 As mentioned in section 3.2, the density of slip amount distribution (gray or white areas) along the slab reflects the slip velocity variety. Different densities of the gray lines in Fig. 10 denote that the slip velocity was temporarily heterogeneous. Some lighter periods are associated to rapid rupture events, whereas some denser periods are associated to slow slip or to smaller 
https://doi.org/10.5194/se-2020-41

Preprint. Discussion started: 7 April 2020

(c) Author(s) 2020. CC BY 4.0 License.

(c) (i)

events. However, the recurrence of rupture events cannot be clearly identified from the accumulated slip distributions. Hence, we recorded the slip velocities respect to the slab along the slab interface and plotted the resultant and vertical slip velocity spectrums in Fig. 11. Since the horizontal slip distribution (Fig. 10 b) along the slab is similar to the resultant one (Fig. 10a), we only dissect the resultant and vertical slip velocity spectrums in Fig. 11.

In the slip velocity spectrum obtained from the whole simulation (Fig. 11), white regions (no slip velocity) represent totally locked patches, light yellow regions corresponds to partially creeping zones (slip velocity is less than $0.012 \mathrm{~m} / 0.2$ year in Fig. $11 \mathrm{a}$ and vertical slip velocity is less than $0.0024 \mathrm{~m} / 0.2$ year in Fig. 11b), and yellow regions represent completely creeping zones (slip velocity is ca. $0.012 \mathrm{~m} / 0.2$ year in Fig. 11a and slip velocity is ca. $0.0024 \mathrm{~m} / 0.2$ year in Fig. $11 \mathrm{~b}$ ). The dark regions indicate occurrences of rupture slip event (slip velocity greater than $0.012 \mathrm{~m} / 0.2$ year in Fig. 11a and vertical slip velocity greater than $0.0024 \mathrm{~m} / 0.2$ year in Fig. 11b). In Fig. 11a, the events associated with large slip velocities, including BE1-3, show long dark lines in the spectrum and thus correspond to large rupture events (also see Figs. 8 and 10). Besides the three big events (BE1-3), the sub-events (SE1-5), shown as the relatively dark color and shorter lines than the big events, happened at years $345,433,464,475$, and 505, respectively, corresponding to a recurrence interval of $40 \pm 29$ (ca. 50) years, which correspond to about one third of the big events recurrence interval (ca. 140 years). The likelihood of these recurrence intervals probably depends on the deviation of slip accumulation or on the distribution of the stress concentration along the slab as discussed in the previous section. Besides these large events, which occurred along the interface between the slab and the frontal prism, the vertical component of the slip velocity spectrum (Fig. 11b) reveals small events along the splay fault (e.g., events in seismic group 1 (SG1) and seismic group 2 (SG2)), which occurred at the back prism segment after the first purple dash line (the seaward base of the seamount).

In Fig. 11b, some smaller events (such as events in SG1 and SG2) can be identified along the interface between the back prism and the slab with rupture length less than $50 \mathrm{~km}$, which is smaller than that between the frontal prism and the slab. However, from the slip velocity spectrum on the top surface of the overriding plate shown in Fig. 12a, we could also identify these events with longer length, probably because of the dip of the splay fault. Thus, we conclude that these events have ruptured from the slab to the surface along the splay fault with rupture lengths $\sim 50 \mathrm{~km}$.

330 Additionally, a low slip velocity region, which is located between the seaward base (the left purple dashed line in Fig. 11b) and the summit (the gray dashed line) of the seamount, suggests that this segment tended to lock with the seaward flank of the seamount. Such behavior could have favored the formation of the splay fault. This low slip velocity region is less evident in the surface slip velocity spectrum presented in Fig. 12b.

335 The slip velocity spectrum shows characteristics of every types of earthquake (big and sub events) in a subduction system. The big events (e.g., BE1-3) ruptured the entire frontal prism along the slab to the trench, with rupture lengths of ca. $100 \mathrm{~km}$ and a 
https://doi.org/10.5194/se-2020-41

Preprint. Discussion started: 7 April 2020

(c) Author(s) 2020. CC BY 4.0 License.

(c) (i)

regular recurrence interval of ca. 140 years. The sub events, which were associated with slips along different parts of the interface between the frontal prism and slab, ruptured along lengths of about $50 \mathrm{~km}$ with a recurrence interval of decades. Some of these sub events (e.g., SE1-4) ruptured the segment close to the trench. Some (e.g., SE5) produced slip along moderate length segments of the slab and may have accumulated stress in the shallow part of the prism. Many ruptures, which produced slips along the interface between the back prism and the slab (i.e., events in SG1-2), reached the surface of the splay fault to generate ca. $50 \mathrm{~km}$ length ruptures. Most of ruptures stopped at the seamount.

\subsection{Slip sequence of the fixed points above the slab}

345 In order to elucidate the slip heterogeneity along the slab, we computed the accumulated slip amounts along the slab and instantaneous velocities at different points above the slab (Figs. 13 and 14).

The resultant slip curves (Fig. 13a) are used to measure the displacement of the given positions along the slab during events in the frontal prism. The cumulated slip increased gradually from point A to point $F$. The slip slope generally increased from

350 A to F between rupture events (e.g., before BE1; between BE1 and SE1), implying that the inter-rupture slip rate increased from the trench landwards.

The resultant slips (Fig. 13a) evidence large coseismic slips (ca. $4 \mathrm{~m}$ ) of the frontal prism during big events, BE1-3, corresponding to the coseismic deformation. Since point A is located at the trench region, it could be affected by shallow disturbance, resulting in different slip behaviors from that of the other points of the frontal prism. The slip curves of points BF clearly indicate the three big events. Nevertheless, the coseismic slips from $\mathrm{C}$ to $\mathrm{F}$ seemed to decrease, because $\mathrm{F}$ is close to the seamount, whereas B and C are close to the free surface. Furthermore, we can also discern slip associated to the sub event SE1 between BE1 and BE2, and slips associated to the three sub events SE2-4 between BE2 and BE3, whereas these sub events are difficult to be identified in the vertical slip curves in Fig. 13b.

The slip patterns of all the points located along the slab in the frontal prism are generally similar to each other (points A-F in Fig. 13), but different from those located in the back prism (points G-K in Fig. 14; even though location of point G belongs to the frontal prism, we discuss this point together with points in the back prism). The slip amount accumulated during 400 years changes from ca. $20 \mathrm{~m}$ at $\mathrm{F}$ to ca. $7.5 \mathrm{~m}$ at $\mathrm{G}$, because $\mathrm{G}$ is close to the seaward base of the seamount and it is thus strongly

365 affected by the seamount subduction. In Fig. 14, it is difficult to identify the big events contrary to Fig. 13, since those ruptures did not propagate over the seamount. From G to K, the general cumulated slip amount increases (Fig. 14). As mentioned previously, the seaward flank of the seamount (points $\mathrm{G}$ and $\mathrm{H}$ ) seemed to lock with the seamount as evidenced from the vertical component curves (Fig. 14b). Points I-K show similar resultant slip patterns, which can be associated to some interrupture slow or small slips (slip amount less than $1 \mathrm{~m}$ ) that occurred during smaller events (indicated by gray arrows in Fig. 
https://doi.org/10.5194/se-2020-41

Preprint. Discussion started: 7 April 2020

(c) Author(s) 2020. CC BY 4.0 License.

(c) (i)

370 14a), which probably belong to the seismic groups (e.g., SG1 or SG2 in Figs. 11 and 12). The vertical slip patterns at points I$\mathrm{K}$ are different due to change of dipping directions when the points went over the summit of the seamount.

From the trench landwards in the frontal prism, the accumulated slip (Figs. 13 and 14) somewhat increased during inter-seismic periods whereas it decreased during coseismic periods. Between the rupture events, the accumulated slip increased gradually

375 from the trench landwards, showing that the shallower the segment was, the more locked the interface is during the interrupture periods. Thus, between rupture events BEs and SEs, the accumulated slip in the frontal prism at distances larger than $50 \mathrm{~km}$ away from the trench (from point $\mathrm{C}$ landwards) also increased gradually from the trench landwards; at shallower level of the interface obtains higher coupling ratio (i.e., seismically locked instead of creeping). The only exception is the region very close to the trench (from Point A to C, ca. $10 \mathrm{~km}$ depth), where was unstable due to its proximity to the surface. The 380 region from points $\mathrm{C}$ to $\mathrm{F}$ (ca. 50-210 km from the trench and ca. 10-45 km depth), gathered the big rupture events (BE1-3). During these rupture events, the coseismic slip could reach ca. $3 \mathrm{~m}$ in this region along the slab. In the back prism and on the landward of the seamount, the region (ca. $45-50 \mathrm{~km}$ depth) can be regarded as a relatively small seismogenic region, since most of events rupture for less than $1 \mathrm{~m}$ along both the subducting interface and the splay fault. Since this region is close to the creeping boundary (backstop boundary), some inter-rupture slips prevailed.

\subsection{Instant velocities above the slab}

To further understand the effect of the seamount on the rupture behavior along the simulated megathrust, we recorded the instantaneous velocity of points A-K during the simulated 400 years.

390 Fig. 15 shows the velocities of points A-F in the frontal prism. When the rupture events occurred, the velocity of the points located in this region should go up to a peak on the velocity spectrum. Previously, we observed conspicuous velocity peaks during the big events BE1-3, especially at points C and D. Note that such coseismic behaviors are unclear for A and B since this shallow part of the frontal prism was unstable as mentioned previously. These peaks tend to be less significant at $\mathrm{F}$, because it is close to the seamount. Comparing the velocity peaks during the three events, the amplitudes of the instantaneous velocity 395 decreased from the trench landwards (from C to F), consistent with the accumulated slip decrease from the trench to the depth during the big events illustrated in Fig. 13. In between these big events, we also observe several peaks, which could be associated with the sub events SE1-5.

We can discern the instantaneous velocity peaks related to the big events BE1-3 in the frontal prism along the slab (Fig. 15), 400 but not in the region close to the seamount (Fig. 16). As we discussed from Fig. 12, these ruptures do not cross the seamount. 
https://doi.org/10.5194/se-2020-41

Preprint. Discussion started: 7 April 2020

(c) Author(s) 2020. CC BY 4.0 License.

(c) (i)

Thus, on the seaward side of the seamount, the slip involves the three big events and five sub-events. On the landward side of the seamount, the slip is related to many small events that occurred along the splay fault.

\section{Comparison of modeling results to observations}

We discuss here our simulation results with respect to observations related to the Sumatran subduction zone. First, we analyze the effect of the seamount geometry on the deformation of the overriding plate and seismic cycles and compare the vertical displacement on the surface with the paleoseismic record in the subduction zone. Then, we compare nucleated splay faulting in the overriding plate with recently seismic observations. Finally, we compare the simulated varies rupture zones with the observed seismic domains along the slab.

\subsection{Analysis of the effect of the seamount at the subduction zones}

The displacements on the surface (Figs. 8 and 9) and along the slab (Figs. 13 and 14), the accumulated slip distribution (Fig. 10), the slip velocity spectrum (Figs. 11 and 12), and the instant velocities along the slab (Figs. 15 and 16) reveal that the

415 seamount divides the deformation of the overriding plate in two distinct zones separated by the splay fault. The seamount acts as a watershed, thus making the displacement paths different in the frontal and back prisms at the surface (Fig. 8c) as well as along the slab (Figs. 13 and 14). The frontal prism tends to subduct before the big events and to rebound during the big evens, whereas the back prism does not respond to big events. Because of the seamount, the big events and sub events (Figs. 13, 14, 15 and 16), which occurred in the frontal prism, do not affect the back prism zone. The coseismic slip behaviors around the zone close to the seamount are more complex; in particular, the region in contact with the seaward flank of the seamount seems to move along with the slab during the subduction (Figs. 11b, 12b, and 14).

The rupture length and the seismic cycle (Figs. 10, 11, and 12) are also different in the two regions separated by the seamount. The rupture length (ca. $100 \mathrm{~km}$ ) in the frontal prism is longer and the cycle (ca. 140 years) is also larger than that in the back prism (ca. $50 \mathrm{~km}$ with few decades interval). The slip patterns (Figs. 11 and 12) show dominant long slips (ca. $100 \mathrm{~km}$ ) associated to a few big events in the frontal prism, and more smaller slips (less than $50 \mathrm{~km}$ ) associated to frequent small events, which also include the small event slips along the splay fault.

In addition, the geometry of the seamount significantly influences the vertical slip along the interface between the slab and the overriding plate. The seamount also accounts for the generation and propagation of the splay fault and back fault in the overriding plate. Even though splay faults might be easy to be generated at the shallow zone with the weak sediments and friction along the slab, it is not easy to be formed by the only friction along the slab at the depth of ca. $30 \mathrm{~km}$. However, the splay fault propagation is observed at Mentawai zone (Wang et al., 2018). Thus, this observed geometry of the seamount might 
https://doi.org/10.5194/se-2020-41

Preprint. Discussion started: 7 April 2020

(c) Author(s) 2020. CC BY 4.0 License.

(c) (i)

be the key factor in the different motion pattern of the frontal and back prism, as well as the cycle of the big events, and it may also be the key factor in generating and rupturing the splay fault at the depth. In the model, ruptures of the big events also terminate at the position of the seamount, since the seamount is the mean feature to accumulate the stress along the slab, and further controls the big rupture cycle.

Thus, the prominent irregularity such as the seamount is the source of the big events at the subduction zones and also the splay fault propagation at depth.

\subsection{Comparison of surface displacement and geological observations}

As described above, the vertical deformation of most part of the frontal prism (e.g., P1) goes downwards (Fig. 8c) in between big events (e.g., BE1) and generally rebounds up during big events. The surface deformation is thus significantly affected by

445 the seismic cycle, as documented in Sieh et al. (2008). Since the projection of the location of Bulasat (Fig. 8) on the seismic profile is close to P1 (red lines in Figs. 8c and 17), we compared the vertical deformation path of P1 and the paleoseismic record of Bulasat (Figs. 1c and 17) (Sieh et al., 2008). Even though the amplitudes of the vertical displacements of P1 and of Bulasat are somewhat different, the overall evolution before and during the events are certainly same. Both in the model and observations, this area (around P1 or the Bulasat) subsides and uplifts before and during big events respectively.

The vertical displacement record of P1 (Figs. 8c and 17), accumulated slip distribution (Fig. 10) and slip velocity spectrum (Fig. 11) shows the recurrence interval of every earthquake (big and sub events) in the subduction system. The resultant slip amount along the interface between the upper plate and the slab can reach up to ca. $4 \mathrm{~m}$. The vertical slip close to P1 on the surface is ca. $0.5 \mathrm{~m}$, comparable to the paleoseismic observations (0.7-2.5 m) from Sieh et al. (2008). The big events (i.e., BE

455 1-3) rupture the entire frontal prism along the slab to the trench, corresponding to rupture lengths of ca. $100 \mathrm{~km}$. They also occur regularly every ca. 140 years, which is overall comparable to the ca. 200 years interpreted from paleoseismic data (Sieh et al., 2008).

Several reasons can cause the discrepancy between the model and the observation. In the model, the geometry of the interface between the slab and overriding plate is simplified. We focused on the main feature (irregularity/seamount) along the slab, and we thus simplified the geometry of the slab as a planar slab. Furthermore, the properties of the material are also not certain, and we did not take into account any heterogeneity, which most probably exist in such tectonically active zones. The real cycle behavior is controlled by many factors (e.g., the chemistry condition inside the overriding plate or along the slab interface), and so far, there are still some factors, which cannot be well constrained. However, through testing our model, we found that 465 the strain-softening is the key factor in the fault generation and propagation. With strain-softening behavior and scaled stress- 
https://doi.org/10.5194/se-2020-41

Preprint. Discussion started: 7 April 2020

(c) Author(s) 2020. CC BY 4.0 License.

(c) (i)

strain relationship of the model, our model is able to simulate the seismic cycle and pre-existing fault (megathrust) or newborn fault (splay and back fault) propagation.

\subsection{Comparison of splay fault and seismic observations}

470 During the seamount subduction, ruptures occur along the megathrust fault, splay thrust (ST) fault and backstop thrust (BT) fault. We also compared our simulation results with the seismic activity observations in the Mentawai region of the Sumatran subduction zone (Wang et al., 2018). Fig. 18a and b present snapshots showing typical crack swarms occurring during one year respectively at the beginning and at the end of the simulated period. The locations of the ST lineation denoted by the crack swarms at these two periods (presented in Fig. 18a and b, respectively) are similar. The crack swarms simulated along the ST is comparable to the seismic activity reported by Wang et al. (2018). Using a seismic catalog recorded by a global network, Wang et al. (2018) could identify two earthquake lineations: one along the slab with a low-angle thrust faulting and another along the splay fault with a high-angle mechanism. Both seismic groups can be clearly shown in our model. The position of the crack swarms along the ST fault and the slab interface are consistent with the seismic observations. Moreover, one of the frontal backthrust (FBT), main backthrust (MBT) and coastal backthrust (CBT) on the surface could correspond to the point where the splay fault propagates to the surface. The width of the faulted back-thrust zone is also similar to what can be observed in Figs. 8 and 9. Thus, the depth, position and dip angle of the splay fault formed in the model is in good agreement with the recent seismic observations.

\subsection{Comparison of the different rupture zones to observations}

485 The shallow, big and small seismogenic regions defined in our model can be compared to the near-trench, central megathrust and downdip domains identified from the seismic observations by Lay et al. (2012).

Along the interface between the frontal prism and slab, the degree of the creeping slip increases from the near trench to the deep regions, whereas the slip during the big events decreases. Here, we can divide the rupture along the slab into three distinguished regions: shallow seismogenic, big seismogenic and small seismogenic regions. The shallow seismogenic region (0-10 km depth) corresponds to the shallowest part of the plate. This region was characterized as the near-trench domain (depth shallower than $15 \mathrm{~km}$ ) from interpretations based on seismicity records (Lay et al., 2012). The downward region (10-45 km depth) concentrates stress and produces large slips during the big rupture events. This region corresponds to the large seismogenic region, which is comparable to the central megathrust domain identified at 15-35 km depth by Lay et al. (2012).

495 In the deeper region at $45-50 \mathrm{~km}$ depth, the rupture might be small when it occurs along the slab only, but it can also be great when the rupture develops along the slab and propagates along the splay fault. This region could thus correspond to the modest seismic region described by Lay et al. (2012). If a rupture in this region does not propagate along the splay fault and arrests at 
https://doi.org/10.5194/se-2020-41

Preprint. Discussion started: 7 April 2020

(c) Author(s) 2020. CC BY 4.0 License.

(c) (i)

the seamount, it could be associated with small events which would result in slow slips and seismic tremors (Lay et al., 2012). This deep region could correspond to the downdip or transitional domain identified by Lay et al. (2012). In our model, the rupture in the downdip or transitional domain somewhat depends on that the slip evolve along the splay fault but not on the seamount subduction. Thus, the region division along the slab with seamount subduction rigorously matches the domain definition from seismic observations (Lay et al., 2012).

\section{Summary}

In this study, we utilized DEM simulations to study the subduction zone at the Mentawai segment in the Sumatra subduction system and inferred the impact of irregularity on the seismic activity in a subduction system. We have simulated the deformation and rupture behavior of the overriding plate during 400 years of the irregularity/seamount subduction. Our main findings are:

1. The modeling results shows different rupture lengths of events, which varies from tens $\mathrm{km}$ to $140 \mathrm{~km}$.

2. The crack swarms are located in three main regions. One is aligned along the interface between the slab and the overriding plate. The other two regions are located in the splay and backthrust fault regions. The position of the simulated splay fault and its angle to the slab are in good agreement with the seismic observations.

3. The proposed model is able to simulate fault nucleation and propagation, and permits to evaluate the recurrence of the megathrust ruptures. Along the interface between the slab and the overriding plate, the seaward flank of the seamount, which tends to be fully locked with the slab, separates the rupture behavior along the slab into two main segments. The shallow part ruptures as a result of the big events, with a regular recurrence interval of ca. 140 years during the modeled 400 years. Each big event ruptures ca. $100 \mathrm{~km}$ on the interface. Besides these big events, there are five sub events, and the repetition of these events is about decades with significant irregularity. The rupture length of these sub events is ca. $50 \mathrm{~km}$. Some sub-events located close to the trench can propagate toward the surface, some located more at depth cannot.

4. On the landward side of the seamount, the deep part shows more small rupture events. These events can propagate along the splay fault toward the surface. The length of these ruptures is greater than $50 \mathrm{~km}$. During these events, the rupture along the splay fault tends to uplift the region between the splay and backstop faults.

5. This is an innovative study using numerical simulation to reproduce and demonstrate the four kinds of seismogenic regions along the slab. Our simulation shows that the distinguished regions, which are divided the rupture, comparable to the domains definition from seismic observations (Lay et al., 2012). 
https://doi.org/10.5194/se-2020-41

Preprint. Discussion started: 7 April 2020

(c) Author(s) 2020. CC BY 4.0 License.

(c) (i)

Though this study, we propose that the subduction zones with the prominent irregularity/seamount located along the slab, such as Mentawii zone, still present the risk of large earthquakes whose occurrence follows the seismic cycle. In particular, if we have observed the rupture along the splay fault at depth and the seamount geometry along the slab, it could happen a megathrust earthquake in the near future (less than ca. 100 years; one earthquake cycle), which will generate strong ground shaking or/and tsunami in a local scale.

\section{Acknowledgements}

The research was entirely funded by the Earth Observatory of Singapore. We thank Professor Sylvain Barbot for the extremely helpful comments and suggestions. P. Tapponnier is grateful to the Asian School of the Environment (ASE) for allowing him

540 to complete this work by extending his contract at NTU for one year and a half. This work is Earth Observatory of Singapore contribution No. M4430217.B50.706022. We note that there are no data sharing issues in the paper since all of the numerical information has been provided in the table and figures.

\section{Code/Data availability}

We implemented the Yade DEM software (see Kozicki and Donzé, 2008, 2009; Šmilauer, 2015 for details), whose flexibility 545 allowed us to define a specific model relevant to study both faulting and slip along faults.

\section{Author contribution}

LJ carried out the simulations and prepared the manuscript. CHC contributed to the result interpretation, wrote manuscript, and administrate project. LS assisted in the development of the methodology and revised the manuscript. AH-F contributed ideas and edited the manuscript. F-VD contributed on the development of the methodology. PT leaded the funding acquisition.

\section{Competing interests}

The authors declare that they have no conflict of interest.

\section{References}

Benesh, N., Plesch, A., Shaw, J., Frost, E., 2007. Investigation of growth fault bend folding using discrete element modeling: Implications for signatures of active folding above blind thrust faults. Journal of Geophysical Research: Solid Earth 112.

555 Cardozo, N., Allmendinger, R.W., Morgan, J.K., 2005. Influence of mechanical stratigraphy and initial stress state on the formation of two fault propagation folds. Journal of Structural Geology 27, 1954-1972.

Cundall, P.A., Strack, O.D.L., 1979. Discrete numerical model for granular assemblies. Geotechnique 29, 47-65. 
https://doi.org/10.5194/se-2020-41

Preprint. Discussion started: 7 April 2020

(c) Author(s) 2020. CC BY 4.0 License.

(c) (i)

Dean, S.L., Morgan, J.K., Fournier, T., 2013. Geometries of frontal fold and thrust belts: Insights from discrete element simulations. Journal of Structural Geology 53, 43-53.

Ding, M., Lin, J., 2016. Deformation and faulting of subduction overriding plate caused by a subducted seamount. Geophysical Research Letters 43, 8936-8944.

Dominguez, S., Lallemand, S., Malavieille, J., Schnürle, P., 1998a. Oblique subduction of the Gagua Ridge beneath the Ryukyu accretionary wedge system: Insights from marine observations and sandbox experiments. Marine Geophysical Research 20, $383-402$.

565 Dominguez, S., Lallemand, S., Malavieille, J., von Huene, R., 1998b. Upper plate deformation associated with seamount subduction. Tectonophysics 293, 207-224.

Dominguez, S., Malavieille, J., Lallemand, S.E., 2000. Deformation of accretionary wedges in response to seamount subduction: Insights from sandbox experiments. Tectonics 19, 182-196.

Duriez, J., Scholtès, L., Donzé, F.-V., 2016. Micromechanics of wing crack propagation for different flaw properties.

570 Engineering Fracture Mechanics 153, 378-398.

Finch, E., Hardy, S., Gawthorpe, R., 2003. Discrete element modelling of contractional fault-propagation folding above rigid basement fault blocks. Journal of Structural Geology 25, 515-528.

Finch, E., Hardy, S., Gawthorpe, R., 2004. Discrete-element modelling of extensional fault-propagation folding above rigid basement fault blocks. Basin Research 16, 489-506.

575 Fournier, T., Morgan, J., 2012. Insights to slip behavior on rough faults using discrete element modeling. Geophysical Research Letters 39.

Gray, G.G., Morgan, J.K., Sanz, P.F., 2014. Overview of continuum and particle dynamics methods for mechanical modeling of contractional geologic structures. Journal of Structural Geology 59, 19-36.

Guo, Y., Morgan, J.K., 2007. Fault gouge evolution and its dependence on normal stress and rock strength - Results of discrete element simulations: Gouge zone properties. Journal of Geophysical Research-Solid Earth 112.

Guo, Y., Morgan, J.K., 2008. Fault gouge evolution and its dependence on normal stress and rock strength - Results of discrete element simulations: Gouge zone micromechanics. Journal of Geophysical Research-Solid Earth 113.

Guo, Y.G., Morgan, J.K., 2004. Influence of normal stress and grain shape on granular friction: Results of discrete element simulations. Journal of Geophysical Research-Solid Earth 109.

585 Guo, Y.G., Morgan, J.K., 2006. The frictional and micromechanical effects of grain comminution in fault gouge from distinct element simulations. Journal of Geophysical Research-Solid Earth 111.

Hardy, S., Finch, E., 2005. Discrete-element modelling of detachment folding. Basin Research 17, 507-520.

Hardy, S., Finch, E., 2006. Discrete element modelling of the influence of cover strength on basement-involved faultpropagation folding. Tectonophysics $415,225-238$. 
https://doi.org/10.5194/se-2020-41

Preprint. Discussion started: 7 April 2020

(c) Author(s) 2020. CC BY 4.0 License.

(c) (i)

590 Hart, R., Cundall, P., Lemos, J., 1988. Formulation of a three-dimensional distinct element model—Part II. Mechanical calculations for motion and interaction of a system composed of many polyhedral blocks, International Journal of Rock Mechanics and Mining Sciences \& Geomechanics Abstracts. Elsevier, pp. 117-125.

Hayes, G.P., Wald, D.J., Johnson, R.L., 2012. Slab1. 0: A three-dimensional model of global subduction zone geometries. Journal of Geophysical Research: Solid Earth 117.

595 Hubbert, M.K., 1937. Theory of scale models as applied to the study of geologic structures. Geol. Soc. Am. Bull. 48, 14591520.

Hubbert, M.K., 1951. Mechanical basis for certain familiar geologic structures. Geol. Soc. Am. Bull. 62, 355-372.

Hughes, A.N., Benesh, N.P., Shaw, J.H., 2014. Factors that control the development of fault-bend versus fault-propagation folds: Insights from mechanical models based on the discrete element method (DEM). Journal of Structural Geology 68, 121-

600141.

Jiao, L., Tapponnier, P., Costa, F., Donzé, F.-V., Scholtès, L., Taisne, B., Wei, S., 2018. Necking and fracking may explain stationary seismicity and full degassing in volcanic silicic spine extrusion. Earth Planet. Sci. Lett. 503, 47-57.

Kozicki, J., Donzé, F.V., 2008. A new open-source software developed for numerical simulations using discrete modeling methods. Computer Methods in Applied Mechanics and Engineering 197, 4429-4443.

605 Kozicki, J., Donzé, F.V., 2009. YADE-OPEN DEM: an open-source software using a discrete element method to simulate granular material. Engineering Computations 26, 786-805.

Lallemand, S.E., Malavieille, J., Calassou, S., 1992. Effects of oceanic ridge subduction on accretionary wedges: experimental modeling and marine observations. Tectonics 11, 1301-1313.

Lay, T., Kanamori, H., Ammon, C.J., Koper, K.D., Hutko, A.R., Ye, L., Yue, H., Rushing, T.M., 2012. Depth-varying rupture

610 properties of subduction zone megathrust faults. Journal of Geophysical Research: Solid Earth 117.

Morgan, J.K., 1999. Numerical simulations of granular shear zones using the distinct element method - 2. Effects of particle size distribution and interparticle friction on mechanical behavior. Journal of Geophysical Research-Solid Earth 104, 27212732.

Morgan, J.K., 2004. Particle dynamics simulations of rate- and state-dependent frictional sliding of granular fault gouge. Pure

615 Appl. Geophys. 161, 1877-1891.

Morgan, J.K., 2006. Volcanotectonic interactions between Mauna Loa and Kilauea: Insights from 2-D discrete element simulations. Journal of Volcanology and Geothermal Research 151, 109-131.

Morgan, J.K., Bangs, N.L., 2017. Recognizing seamount-forearc collisions at accretionary margins: Insights from discrete numerical simulations. Geology 45, 635-638.

620 Morgan, J.K., Boettcher, M.S., 1999. Numerical simulations of granular shear zones using the distinct element method - 1. Shear zone kinematics and the micromechanics of localization. Journal of Geophysical Research-Solid Earth 104, 2703-2719. Morgan, J.K., McGovern, P.J., 2005a. Discrete element simulations of gravitational volcanic deformation: 1. Deformation structures and geometries. Journal of Geophysical Research-Solid Earth 110. 
https://doi.org/10.5194/se-2020-41

Preprint. Discussion started: 7 April 2020

(c) Author(s) 2020. CC BY 4.0 License.

(c) (i)

Morgan, J.K., McGovern, P.J., 2005b. Discrete element simulations of gravitational volcanic deformation: 2. Mechanical analysis. Journal of Geophysical Research-Solid Earth 110.

Oakley, A.J., Taylor, B., Fryer, P., Moore, G.E., Goodliffe, A.M., Morgan, J.K., 2007. Emplacement, growth, and gravitational deformation of serpentinite seamounts on the Mariana forearc. Geophysical Journal International 170, 615-634.

Okubo, S., Fukui, K., 1996. Complete stress-strain curves for various rock types in uniaxial tension, International journal of rock mechanics and mining sciences \& geomechanics abstracts. Elsevier, pp. 549-556.

Peltzer, G., 1988. Centrifuged expermiments of continental scale tectonics in Asia. Bulletin of the Geological Institution of the University of Upsala 14, 115-128.

Ruh, J.B., 2016. Submarine landslides caused by seamounts entering accretionary wedge systems. Terra Nova 28, 163-170.

Ruh, J.B., Sallarès, V., Ranero, C.R., Gerya, T., 2016. Crustal deformation dynamics and stress evolution during seamount subduction: High-resolution 3-D numerical modeling. Journal of Geophysical Research: Solid Earth 121, 6880-6902.

635 Scholtès, L., Donzé, F.V., 2013. A DEM model for soft and hard rocks: Role of grain interlocking on strength. J. Mech. Phys. Solids 61, 352-369.

Scholz, C.H., Small, C., 1997. The effect of seamount subduction on seismic coupling. Geology 25, 487-490.

Seyferth, M., Henk, A., 2006. A numerical sandbox: high-resolution distinct element models of halfgraben formation. International Journal of Earth Sciences 95, 189-203.

640 Sieh, K., Natawidjaja, D.H., Meltzner, A.J., Shen, C.-C., Cheng, H., Li, K.-S., Suwargadi, B.W., Galetzka, J., Philibosian, B., Edwards, R.L., 2008. Earthquake supercycles inferred from sea-level changes recorded in the corals of west Sumatra. Science 322, 1674-1678.

Singh, S.C., Hananto, N., Mukti, M., Robinson, D.P., Das, S., Chauhan, A., Carton, H., Gratacos, B., Midnet, S., Djajadihardja, Y., 2011. Aseismic zone and earthquake segmentation associated with a deep subducted seamount in Sumatra. Nature

645 Geoscience 4, 308-311.

Šmilauer, V., 2015. Yade Documentation 2nd ed. The Yade Project.

Strayer, L., Suppe, J., Graveleau, F., 2010a. Numerical Modeling of Detachment Folding: a 2D Approach with Application to Incremental Coseismic Fold Growth in Taiwan, EGU General Assembly Conference Abstracts, p. 7303.

Strayer, L., Suppe, J., Lee, P., 2010b. A Toy Model Investigation of the Weak-Fault Strong-Crust Problem, EGU General

650 Assembly Conference Abstracts, p. 6429.

Strayer, L.M., Suppe, J., 2002. Out-of-plane motion of a thrust sheet during along-strike propagation of a thrust ramp: a distinct-element approach. Journal of Structural Geology 24, 637-650.

Waltz, J., Morgan, N.R., Canfield, T.R., Charest, M.R.J., Risinger, L.D., Wohlbier, J.G., 2014. A three-dimensional finite element arbitrary Lagrangian-Eulerian method for shock hydrodynamics on unstructured grids. Computers \& Fluids 92, 172655187.

Wang, K., Bilek, S.L., 2011. Do subducting seamounts generate or stop large earthquakes? Geology 39, 819-822. 
https://doi.org/10.5194/se-2020-41

Preprint. Discussion started: 7 April 2020

(c) Author(s) 2020. CC BY 4.0 License.

Wang, K., Bilek, S.L., 2014. Invited review paper: Fault creep caused by subduction of rough seafloor relief. Tectonophysics 610, 1-24.

Wang, X., Bradley, K.E., Wei, S., Wu, W., 2018. Active backstop faults in the Mentawai region of Sumatra, Indonesia, revealed by teleseismic broadband waveform modeling. Earth Planet. Sci. Lett. 483, 29-38.

Yang, H., Liu, Y., Lin, J., 2012. Effects of subducted seamounts on megathrust earthquake nucleation and rupture propagation. Geophysical Research Letters 39.

Yang, H., Liu, Y., Lin, J., 2013. Geometrical effects of a subducted seamount on stopping megathrust ruptures. Geophysical Research Letters 40, 2011-2016.

665 Yu, H., Liu, Y., Yang, H., Ning, J., 2018. Modeling earthquake sequences along the Manila subduction zone: Effects of threedimensional fault geometry. Tectonophysics 733, 73-84.

Zhang, J., Morgan, J.K., Gray, G.G., Harkins, N.W., Sanz, P.F., Chikichev, I., 2013. Comparative FEM and DEM modeling of basement-involved thrust structures, with application to Sheep Mountain, Greybull area, Wyoming. Tectonophysics 608, 408-417. 
https://doi.org/10.5194/se-2020-41

Preprint. Discussion started: 7 April 2020

(c) Author(s) 2020. CC BY 4.0 License.

Table 1. Model Parameters Used in the Simulation

\begin{tabular}{|c|c|c|c|c|}
\hline \multicolumn{2}{|l|}{ Parameter } & Symbol & Value & Unit \\
\hline \multicolumn{2}{|c|}{ Number of elements } & - & 12,000 & - \\
\hline \multicolumn{2}{|c|}{ Mean element radius } & $\boldsymbol{R}$ & 0.99 & [km] \\
\hline \multicolumn{2}{|c|}{$\begin{array}{l}\text { Ratio of largest to smallest } \\
\text { element }\end{array}$} & - & 1.86 & {$[-]$} \\
\hline \multicolumn{2}{|c|}{ Interaction range coefficient } & $\gamma_{\text {int }}$ & 1.2 & {$[-]$} \\
\hline \multirow{6}{*}{$\begin{array}{l}\text { Bonds } \\
\text { between } \\
\text { particles in } \\
\text { the overriding } \\
\text { plate }\end{array}$} & $\begin{array}{l}\text { Elastic } \\
\text { modulus }\end{array}$ & $E$ & 15 & [MPa] \\
\hline & $\begin{array}{l}\text { Tangential } \\
\text { stiffness } \\
\text { coefficient }\end{array}$ & $a$ & 0.01 & {$[-]$} \\
\hline & $\begin{array}{l}\text { Tensile } \\
\text { strength }\end{array}$ & $t$ & 0.3 & [MPa] \\
\hline & Cohesion & $c$ & 0.3 & [MPa] \\
\hline & $\begin{array}{l}\text { Weakening } \\
\text { coefficient }\end{array}$ & $s$ & 2 & {$[-]$} \\
\hline & Friction & $\mu$ & $\mathbf{0}$ & {$[-]$} \\
\hline \multirow{6}{*}{$\begin{array}{l}\text { Bonds } \\
\text { between } \\
\text { particles along } \\
\text { the interface } \\
\text { between the } \\
\text { slab and the } \\
\text { overriding } \\
\text { plate }\end{array}$} & $\begin{array}{l}\text { Elastic } \\
\text { modulus }\end{array}$ & $E$ & 7 & [MPa] \\
\hline & $\begin{array}{l}\text { Tangential } \\
\text { stiffness } \\
\text { coefficient }\end{array}$ & $a$ & 0.01 & {$[-]$} \\
\hline & $\begin{array}{l}\text { Tensile } \\
\text { strength }\end{array}$ & $t$ & 0.14 & [MPa] \\
\hline & Cohesion & $c$ & 0.14 & [MPa] \\
\hline & $\begin{array}{l}\text { Weakening } \\
\text { coefficient }\end{array}$ & $s$ & 2 & {$[-]$} \\
\hline & Friction & $\mu$ & $\mathbf{0}$ & {$[-]$} \\
\hline \multicolumn{2}{|c|}{ Gravitational acceleration } & $g$ & 10 & {$\left[\mathbf{m} / \mathbf{s}^{2}\right]$} \\
\hline \multicolumn{2}{|c|}{ Density } & $\rho$ & 2700 & {$\left[\mathrm{~kg} / \mathrm{m}^{3}\right]$} \\
\hline \multicolumn{2}{|c|}{ Damping coefficient } & $D_{a}$ & 0.4 & {$[-]$} \\
\hline \multicolumn{2}{|c|}{ Time interval coefficient } & - & 0.4 & {$[-]$} \\
\hline
\end{tabular}


https://doi.org/10.5194/se-2020-41

Preprint. Discussion started: 7 April 2020

(c) Author(s) 2020. CC BY 4.0 License.
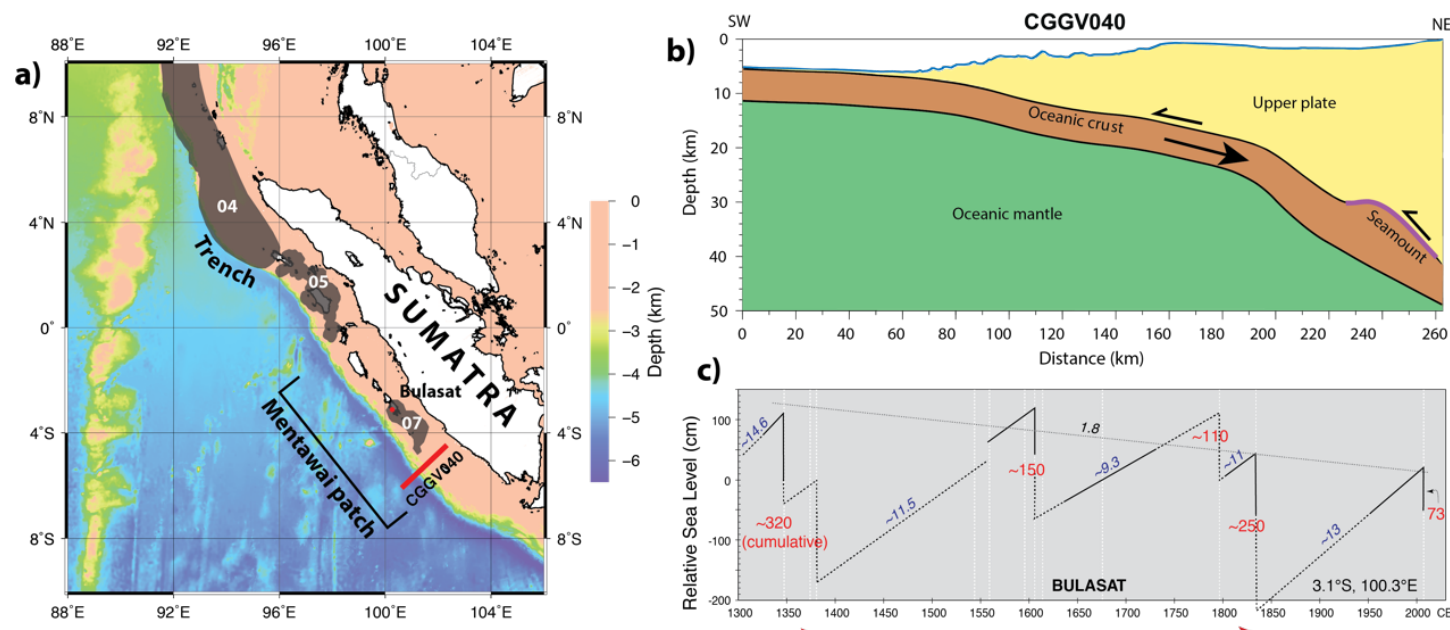

c)

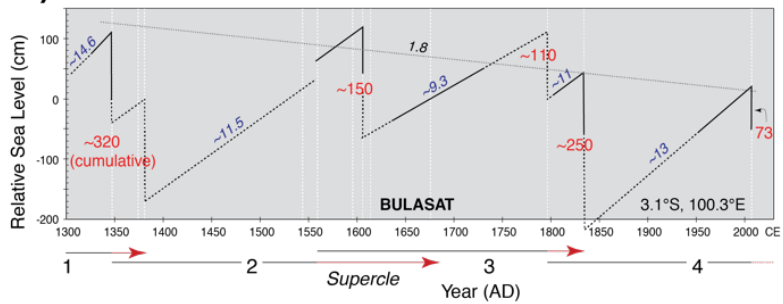

Figure 1: (a) Geological setting at the Mentawai zone. The location of the CGGV040 seismic reflection profile (red line) and the location of the paleoseismic history study (red dot) are located on the Mentawai patch. The three grey semi-transparent areas from north to south are ruptures of M9.2 (2004), M8.6 (2005) and M8.4 (2007), respectively; b) the interpreted cross-section of the CGGV040 (Singh et al., 2011) shows the geometry of the subducting slab with a seamount (in a purple shape) at the depth of ca. 30$40 \mathrm{~km}$; c) earthquake cycles from the paleoseismic records at Bulasat (Sieh et al., 2008) show the big rupture events repeat every ca. 200 years and result the vertical slips of ca. $0.7-2.5 \mathrm{~m}$. In addition, this paleoseismic model infers that the big rupture event at the Mentawai zone will repeat in the future. 
https://doi.org/10.5194/se-2020-41

Preprint. Discussion started: 7 April 2020

(c) Author(s) 2020. CC BY 4.0 License.
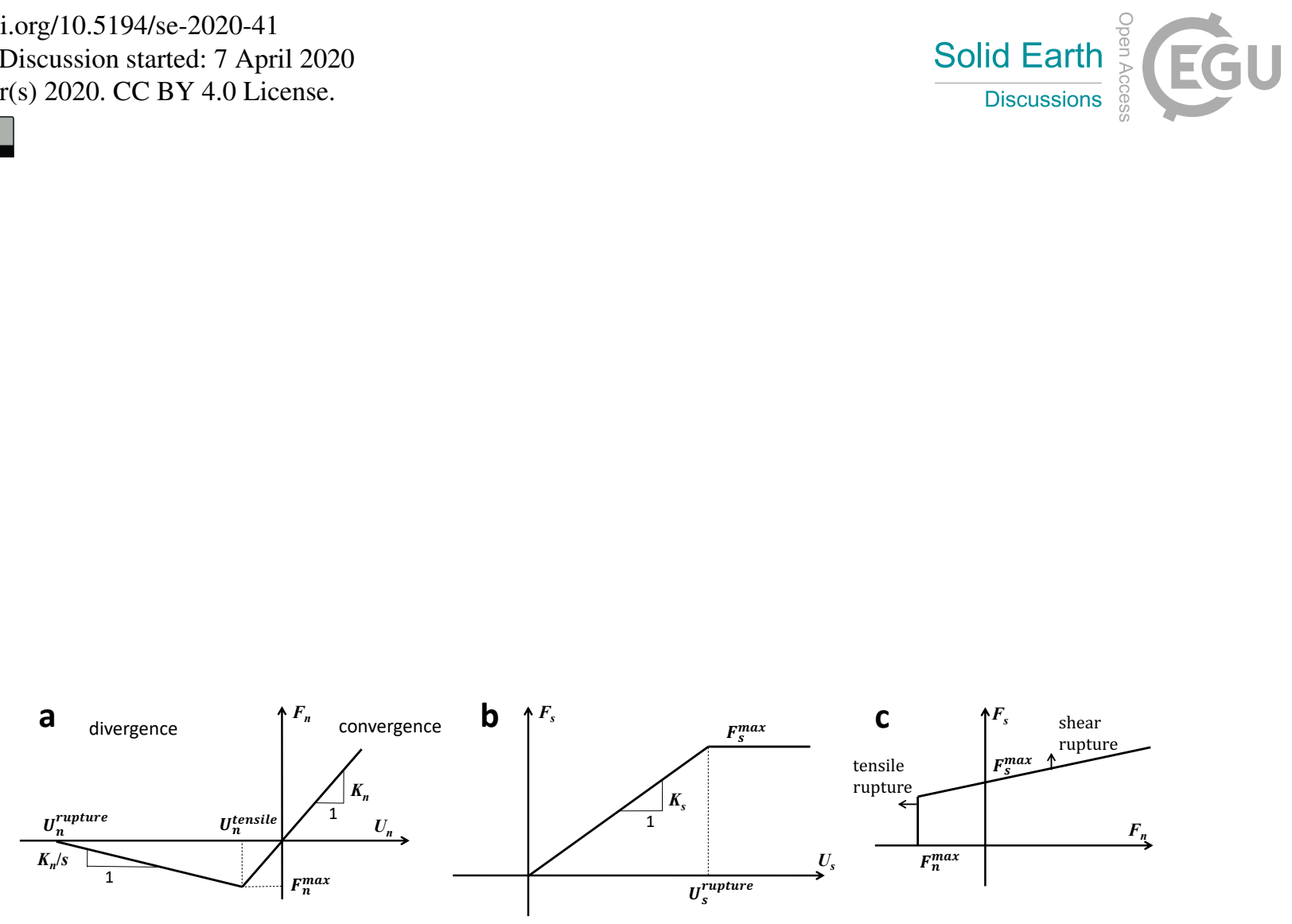

700 Figure 2: The contact model used in the simulations: (a) normal behavior, (b) tangential behavior, and (c) failure envelope. 
https://doi.org/10.5194/se-2020-41

Preprint. Discussion started: 7 April 2020

(c) Author(s) 2020. CC BY 4.0 License.

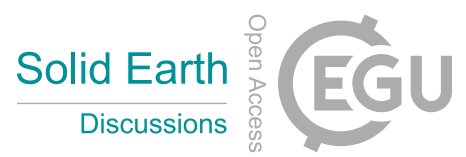
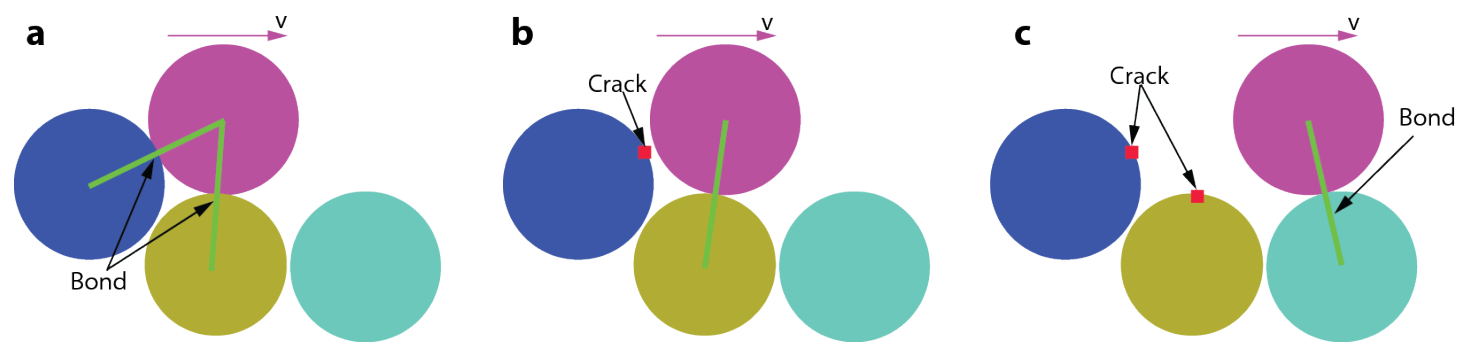

710 Figure 3: Illustration of kinematics and interparticle bond behavior for particles initially in contact (a) and generation of cracks (b) and the new bond (c). The purple particle is moving towards the right side. 
https://doi.org/10.5194/se-2020-41

Preprint. Discussion started: 7 April 2020

(c) Author(s) 2020. CC BY 4.0 License.

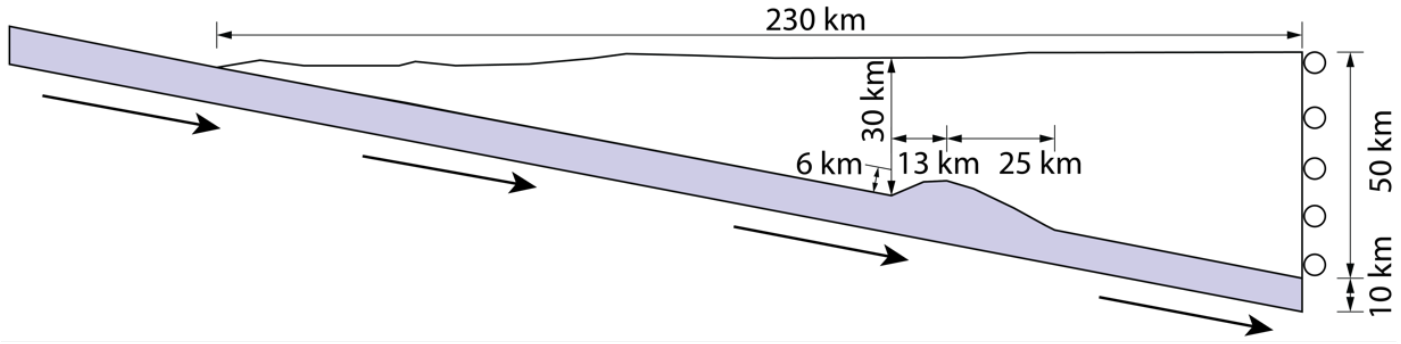

Figure 4: The model geometry: the right boundary of the overriding plate is fixed, and the slab is subducting at ca. $6.12 \mathrm{~cm} / \mathrm{year}$. 
https://doi.org/10.5194/se-2020-41

Preprint. Discussion started: 7 April 2020

(c) Author(s) 2020. CC BY 4.0 License.

a)

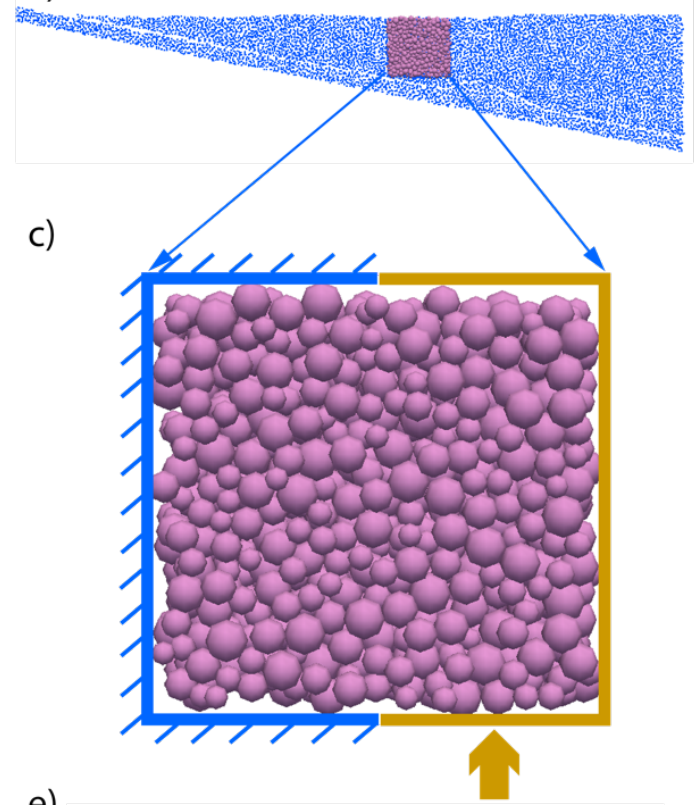

e)

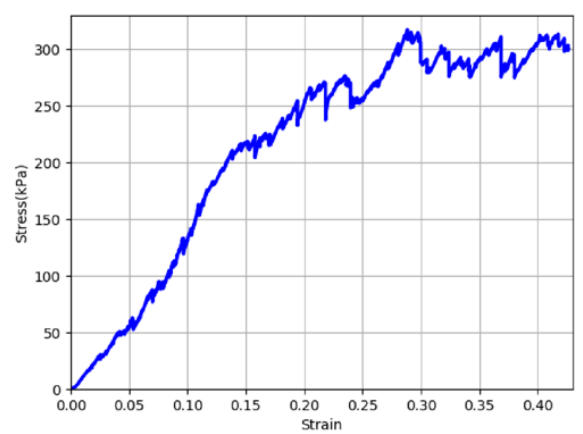

b)

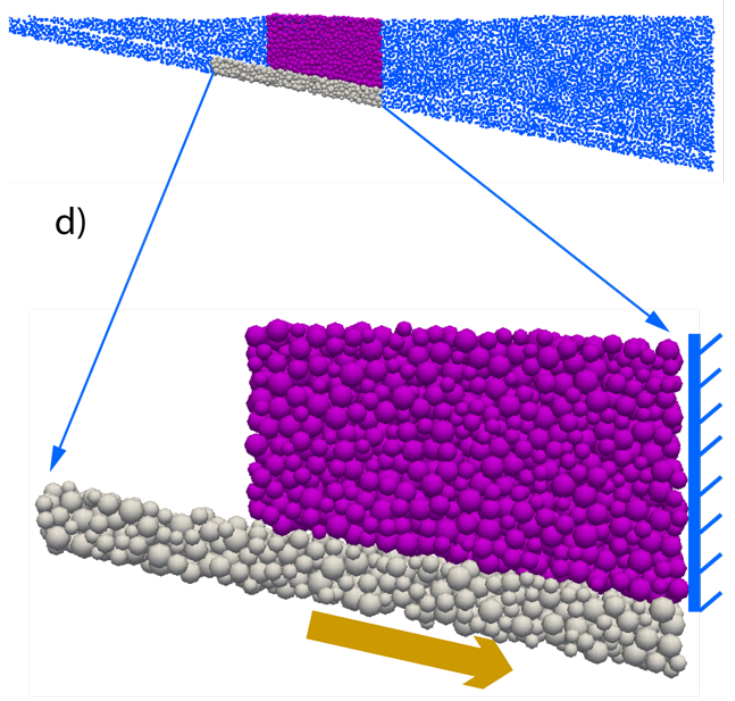

f)

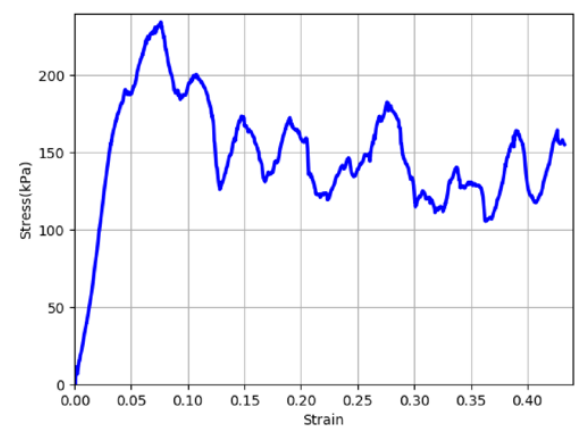

Figure 5: Modeling calibration includes two shear tests for the generated and pre-existing fault. (a) and (b) show the blocks we took from the entire model for the shear tests. (c) shows the simple shear test setting for the generated fault: the blue boundaries are fixed, and the shear loading is exerted on the yellow boundaries. Since we simulate the fault strength on average at depth $\sim 15 \mathrm{~km}$, we also apply the $\sim 400 \mathrm{kPa}$ (hydrostatic pressure $\rho \mathrm{gh}$ ) lateral stress in this test. (d) shows the shear test for the pre-existing fault, which is part of the simulated megathrust fault: the blue boundary constrains the displacement of the purple block, and the loading velocity is applied on the white block. (e) and (f) show the stress-strain curves of the generated fault and pre-existing faults respectively. 
https://doi.org/10.5194/se-2020-41

Preprint. Discussion started: 7 April 2020

(C) Author(s) 2020. CC BY 4.0 License.

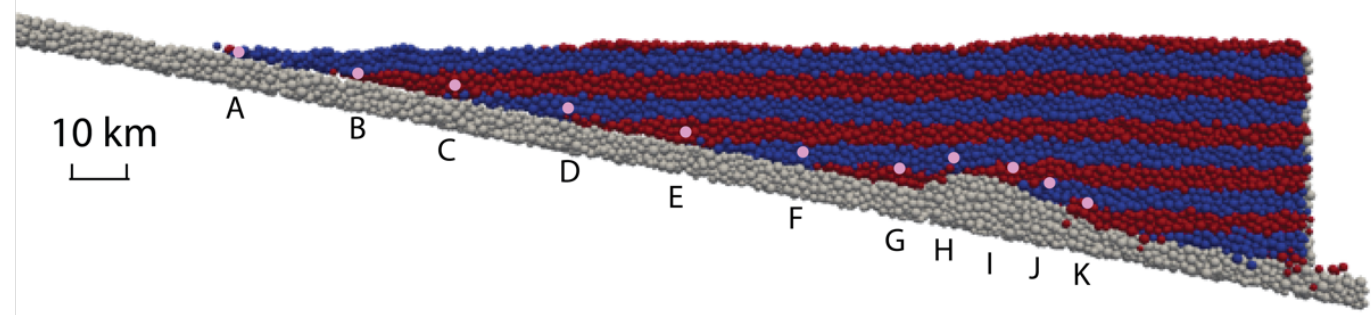

Figure 6: The initial state (initial balance situation): the layers with different colors inside the overriding plate help identify how the overriding plate deformed; the key reference locations (Point A to B just above the slab and Point $\mathrm{C}$ to $\mathrm{K}$ ca. $5 \mathrm{~km}$ above the slab) are marked here for the later analysis. 
https://doi.org/10.5194/se-2020-41

Preprint. Discussion started: 7 April 2020

(c) Author(s) 2020. CC BY 4.0 License.

sur.tan? GGU

745

750

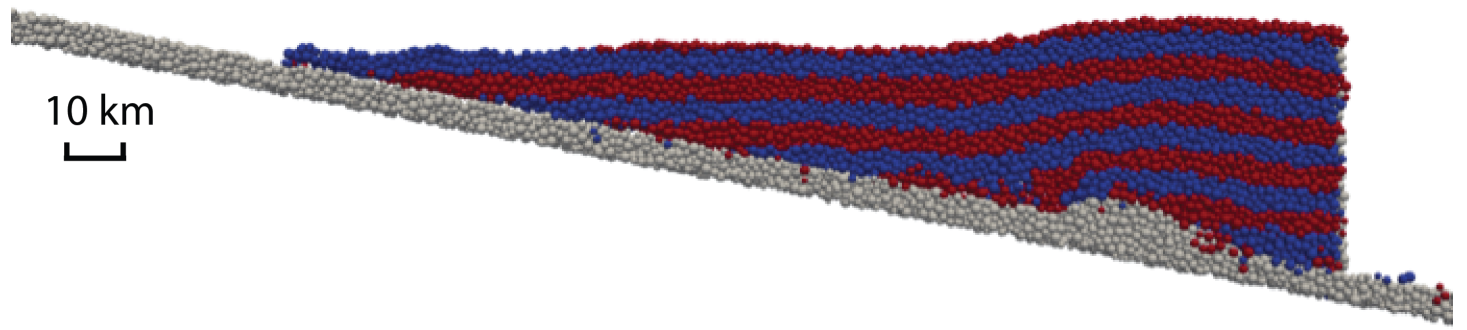

Figure 7: Final deformation after ca. 400 years. 
https://doi.org/10.5194/se-2020-41

Preprint. Discussion started: 7 April 2020

(c) Author(s) 2020. CC BY 4.0 License.
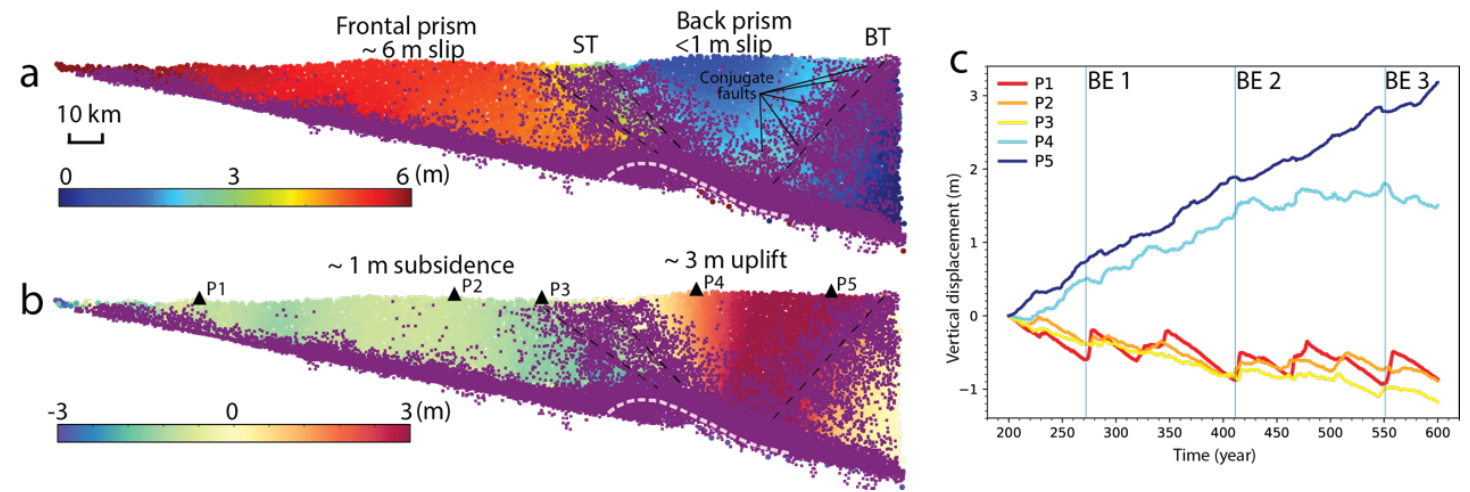

Figure 8: Displacement values of the overriding plate during 400 years (the seamount is represented as a pink dash line) including (a) horizontal component, (b) vertical component; (c) vertical displacement record of points P1-P5 (in (b)) with three vertical light blue lines in order to indicate the positions of the three big events in the model. Cracks (purple dots) align along megathrust faults, splay thrust fault (ST), and back thrust fault (BT), respectively. The color fields reveal that the displacement distribution of the overriding plate. The locations of conjugation faults are identified in (a). 
https://doi.org/10.5194/se-2020-41

Preprint. Discussion started: 7 April 2020

(c) Author(s) 2020. CC BY 4.0 License.
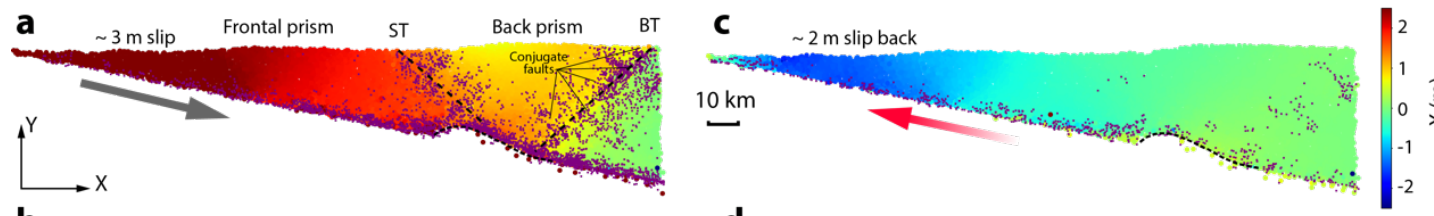

b $~ 0.6 \mathrm{~m}$ subsidence

d $\sim 0.4 \mathrm{~m}$ uplift
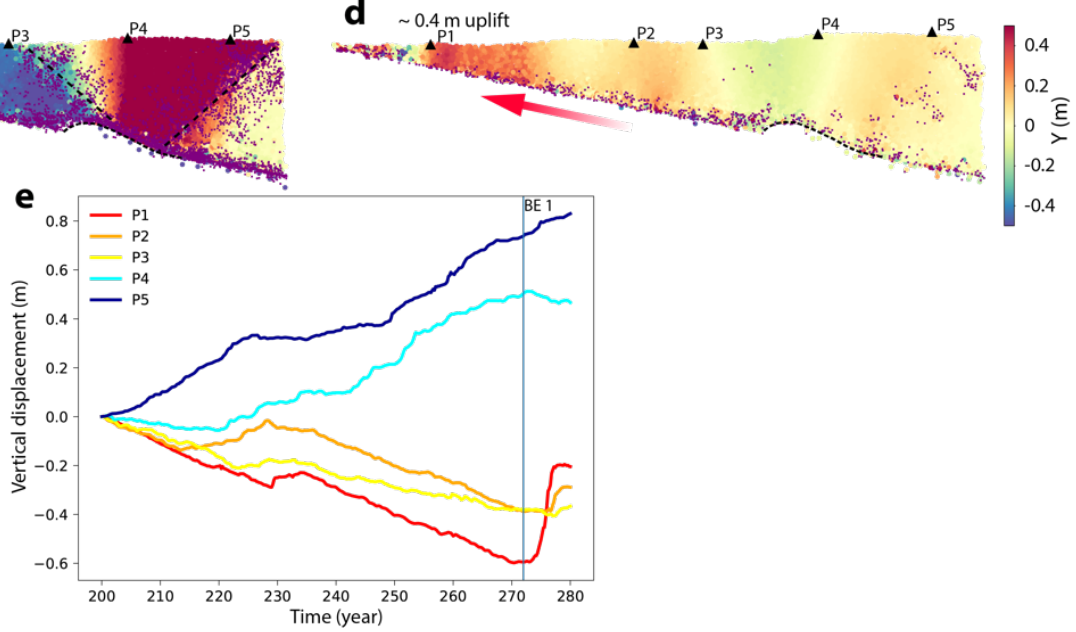

Figure 9: Displacement values of the overriding plate during the first cycle (80 years), which is identified from Fig. 8c: (a) and (b) are horizontal and vertical components respectively before the first big event, (c) and (d) are horizontal and vertical components respectively during the first big event, (e) records the historical path of Points $\mathbf{1 - 5}$ in the first cycle and the vertical light blue line is the start position of the first big event; Cracks, ST, BT, P1-P5 and conjugate faults are the same as Fig. 8. Grey and red arrows show the movement direction of the overriding plates before and after the big event respectively. 

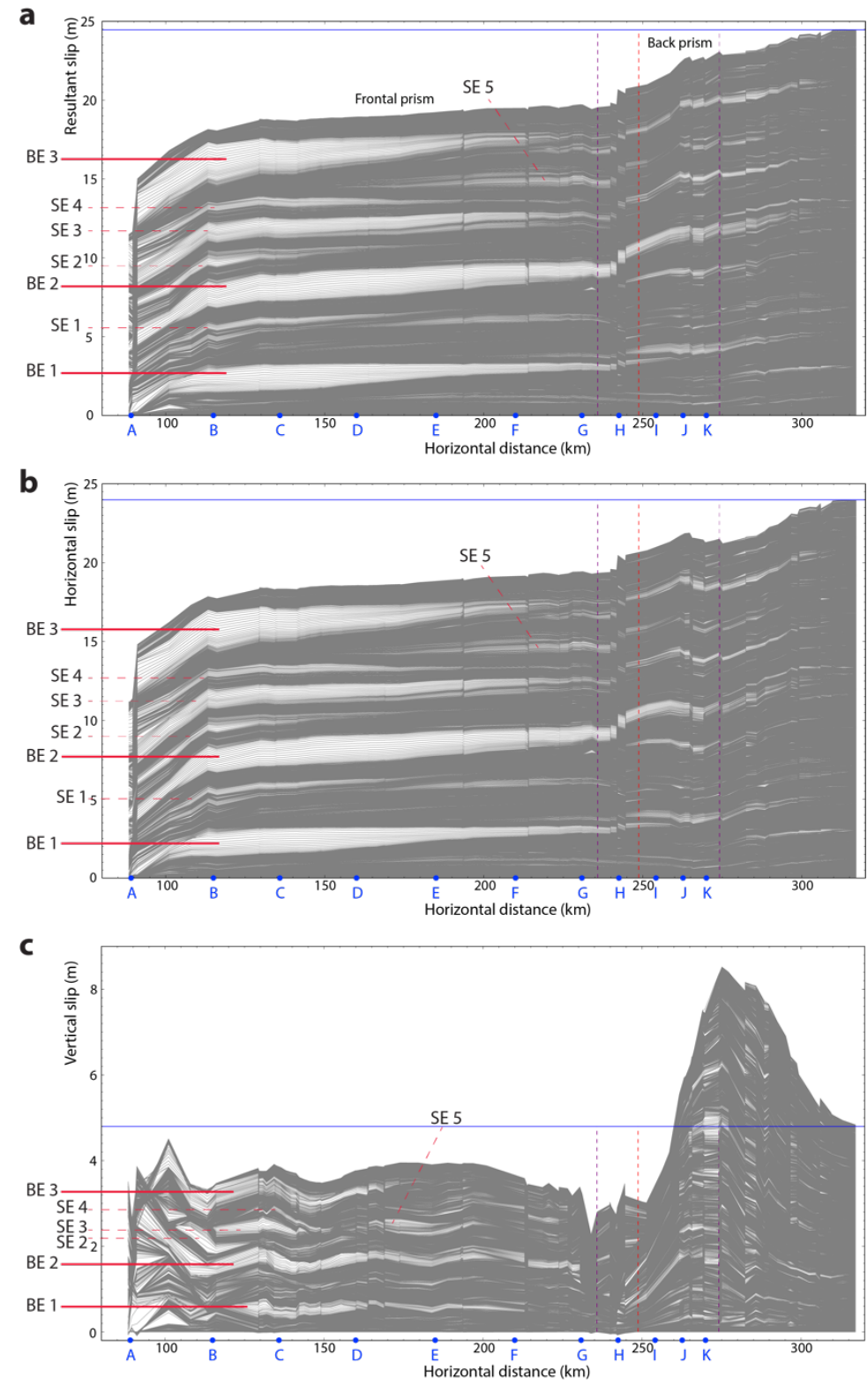

Figure 10: Accumulated slip along the slab interface measured during the simulated 400 years of subduction: (a) accumulated resultant slip relative to the slab, (b) horizontal component and (c) vertical component. Gray lines show accumulated amount of slip along the slab every 0.2 years. The lighter areas reflect fast slip associated with big events. These big events (BE1-BE3) rupture ca. $100 \mathrm{~km}$ of the slab interface. Sub-events (SE1-SE5) only rupture smaller patches (ca. $50 \mathrm{~km})$. At the front of the accretionary prism, slip events mostly rupture the slab interface. In the back of the prism, most events produce uplift deformation, with relatively shorter rupture length. The left purple, red and right purple dashed lines show the sites of the seaward base, summit and landward base of the seamount, respectively. The left purple and red lines bound the splay fault nucleation region along the slab. The key reference locations (Point A to $\mathrm{K}$ ) are denoted in Fig. 6. 
https://doi.org/10.5194/se-2020-41

Preprint. Discussion started: 7 April 2020

(c) Author(s) 2020. CC BY 4.0 License.

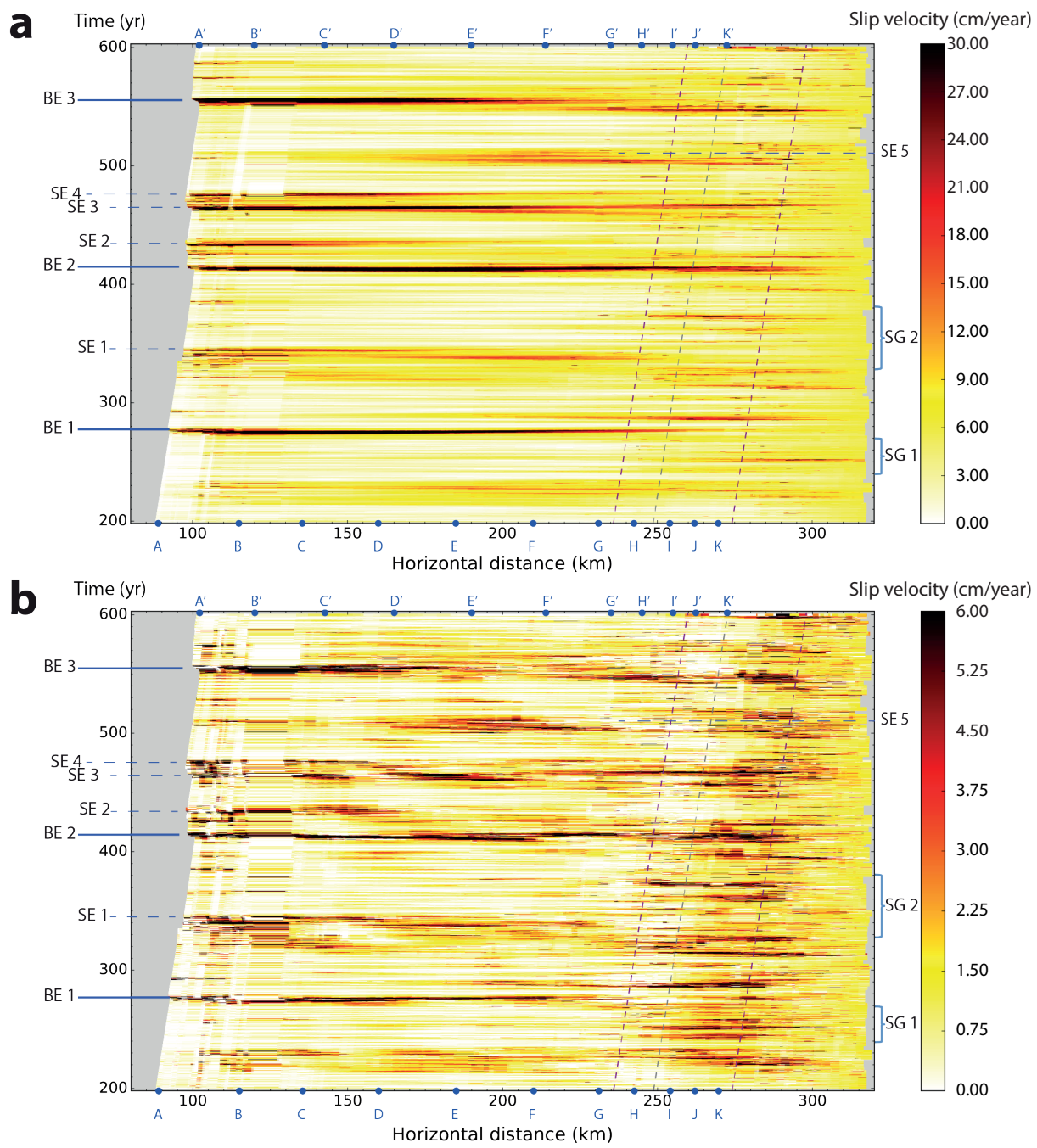

Figure 11: Slip velocity spectrum along the slab: (a) resultant slip velocity and (b) vertical component of slip velocity along the slab. The recurrence interval of big events is ca. 140 years. Relatively smaller events concentrated along the splay fault (e.g. events in SG1-2) are best observed in the vertical component distribution. Every line represents the slip velocity along the slab per scaled 0.2 years over the simulated 400 years. The left purple, gray and right purple dashed lines are the sites of the seaward base, summit and landward base of the seamount, respectively; light yellow region on the seaward side of the seamount indicates lower slip rate along the interface; The key reference locations (Point A to K) are denoted in Fig. 6. 
https://doi.org/10.5194/se-2020-41

Preprint. Discussion started: 7 April 2020

(c) Author(s) 2020. CC BY 4.0 License.

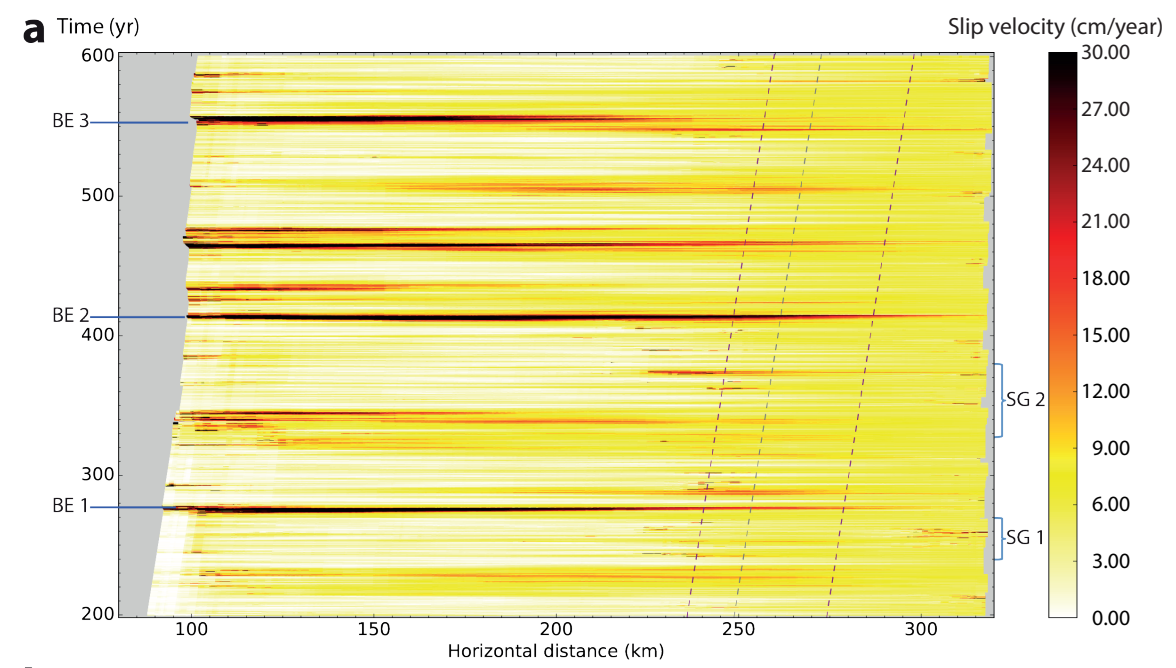

b

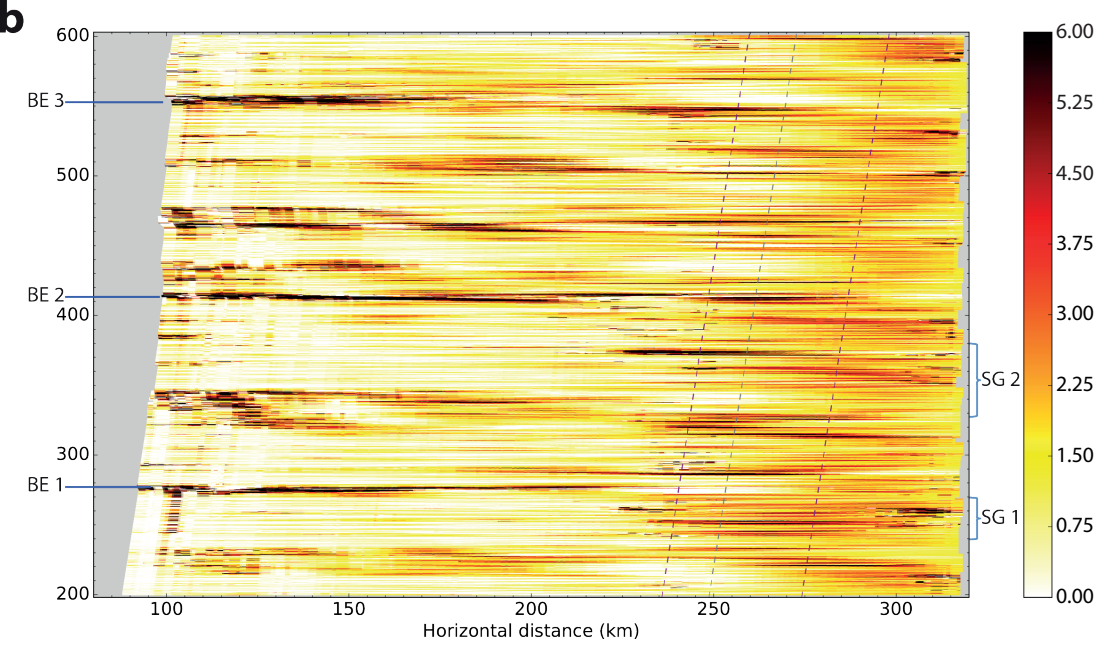

795 Figure 12: Slip velocity spectrum along the top surface of the overriding plate: (a) resultant slip velocity; (b) vertical component of the slip velocity. Surface slip amount also show the big events and sub-events; but the light yellow region (between the left purple and gray dashed lines) is not as clear as that in Fig. 11; the splay fault group rupture longer over the entire seamount, because of the dip of the splay fault (Figs. 8 and 9). The left purple, gray and right purple dashed lines are the sites of the seaward base, summit and landward base of the seamount, respectively. 
https://doi.org/10.5194/se-2020-41

Preprint. Discussion started: 7 April 2020

(c) Author(s) 2020. CC BY 4.0 License.
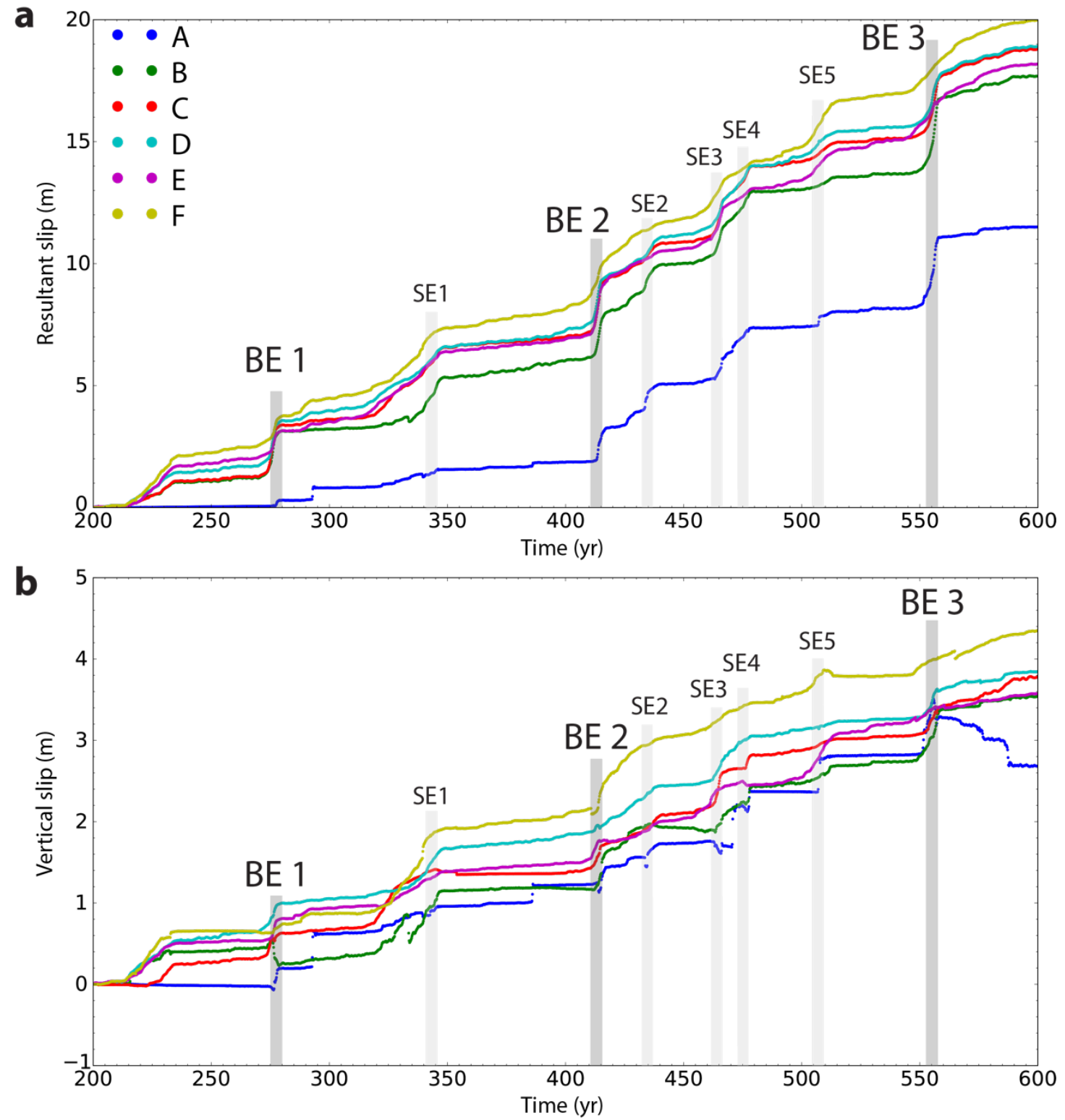

Figure 13: The accumulated slip of Point $A$ to $F$ in the frontal prism defined in Figs. 10 and 11: (a) resultant slip and (b) vertical component along the slab. During the big events BE 1-3, the slip suddenly increases, suggesting significant coseismic slips. The accumulative slip from Point A to F increases whereas the coseismic slips of the big events decreases. Between BE1 and BE2, there is a sub-event, SE1. Between BE2 and BE3, there are four sub-events, SE2-5, which can be identified in (a), but are not clear in (b). The key reference locations (Point A to F) are denoted in Fig. 6. 
https://doi.org/10.5194/se-2020-41

Preprint. Discussion started: 7 April 2020

(c) Author(s) 2020. CC BY 4.0 License.
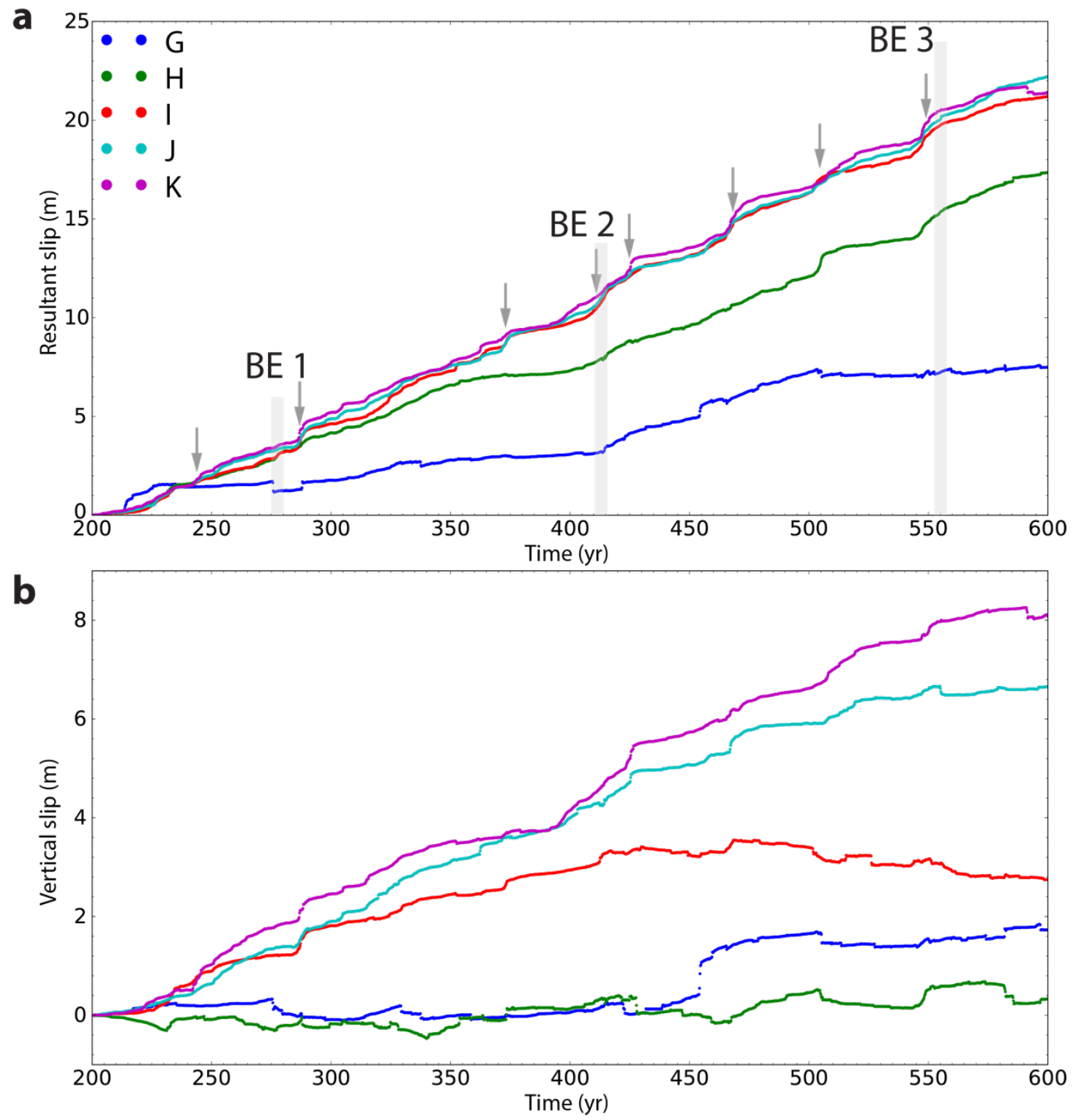

810 Figure 14: The accumulated slip of Point $G$ to $K$ which are close to the seamount as denoted in Figs. 10 and 11: (a) resultant slip and (b) vertical component along the slab. Gray arrows, which are different from the light gray bars (BE1-3), indicate the small corupture slips during smaller events from Point $I$ to $K$ curves. Point $G$ and $H$ are close to the seamount, thus co-rupture slip behaviors around them are more complex. The slips generally increase from Point $\mathbf{G}$ to $\mathrm{K}$. Their slip patterns show more co-rupture slips of frequent small events, which are related to the events slip along the splay fault. The vertical component pattern shows the local seamount geometry effect. The key reference locations (Point G to K) are denoted in Fig. 6. 
https://doi.org/10.5194/se-2020-41

Preprint. Discussion started: 7 April 2020

(c) Author(s) 2020. CC BY 4.0 License.

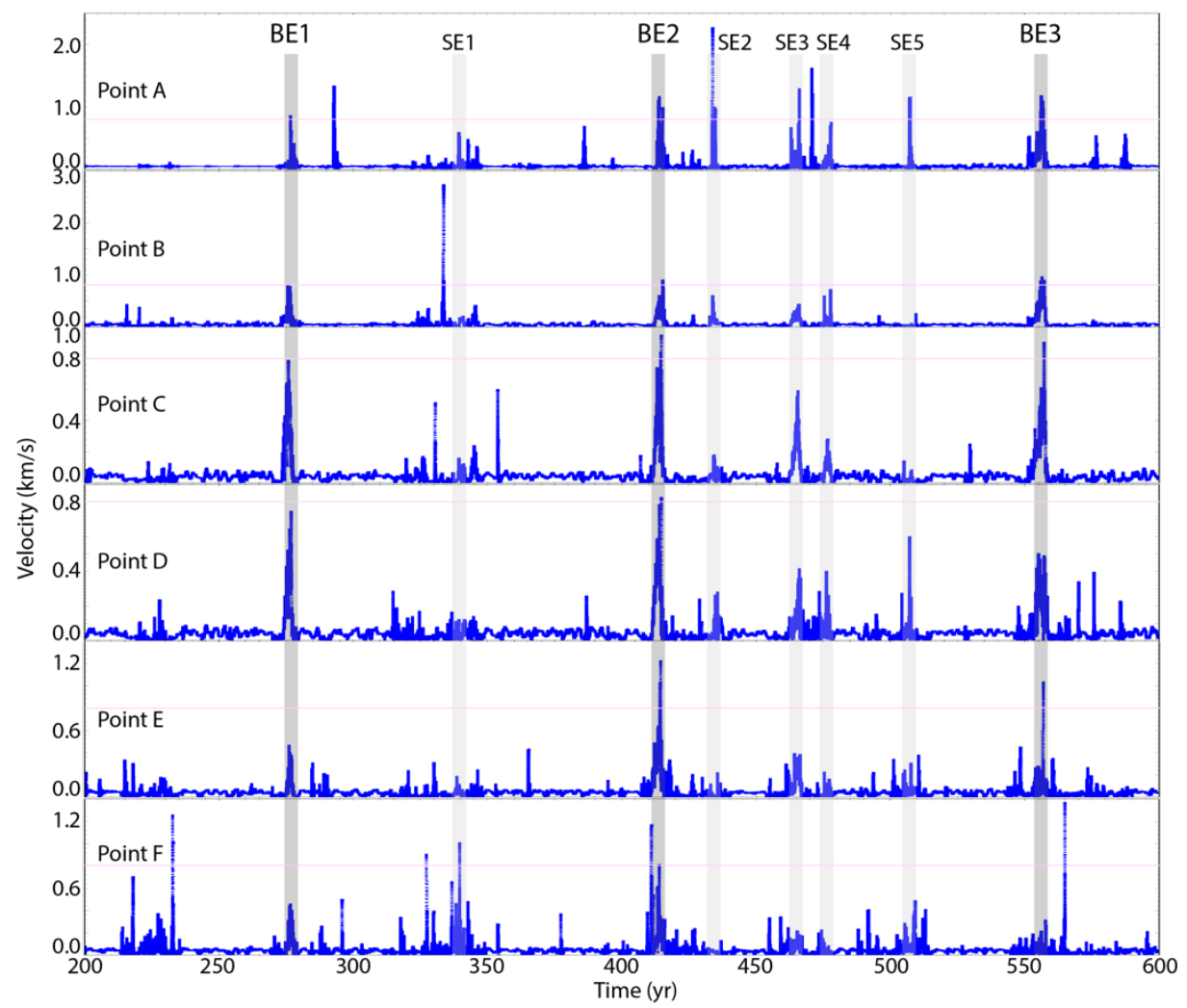

Figure 15: Instantaneous velocity spectrums of Point $A$ to $F$ in the frontal prism along the slab during the simulated 400 years. Three main peaks can be identified corresponding to the big events BE1-3. There are also smaller peaks related to sub events SE1-5. The amplitude of the three main peaks decreases from Point A to F. Note that the velocity at each Point does not use the same scale. The horizontal light pink line corresponds to a velocity of $0.8 \mathrm{~km} / \mathrm{s}$, for reference. The key reference locations (Point A to F) are denoted in Fig. 6. 
https://doi.org/10.5194/se-2020-41

Preprint. Discussion started: 7 April 2020

(c) Author(s) 2020. CC BY 4.0 License.

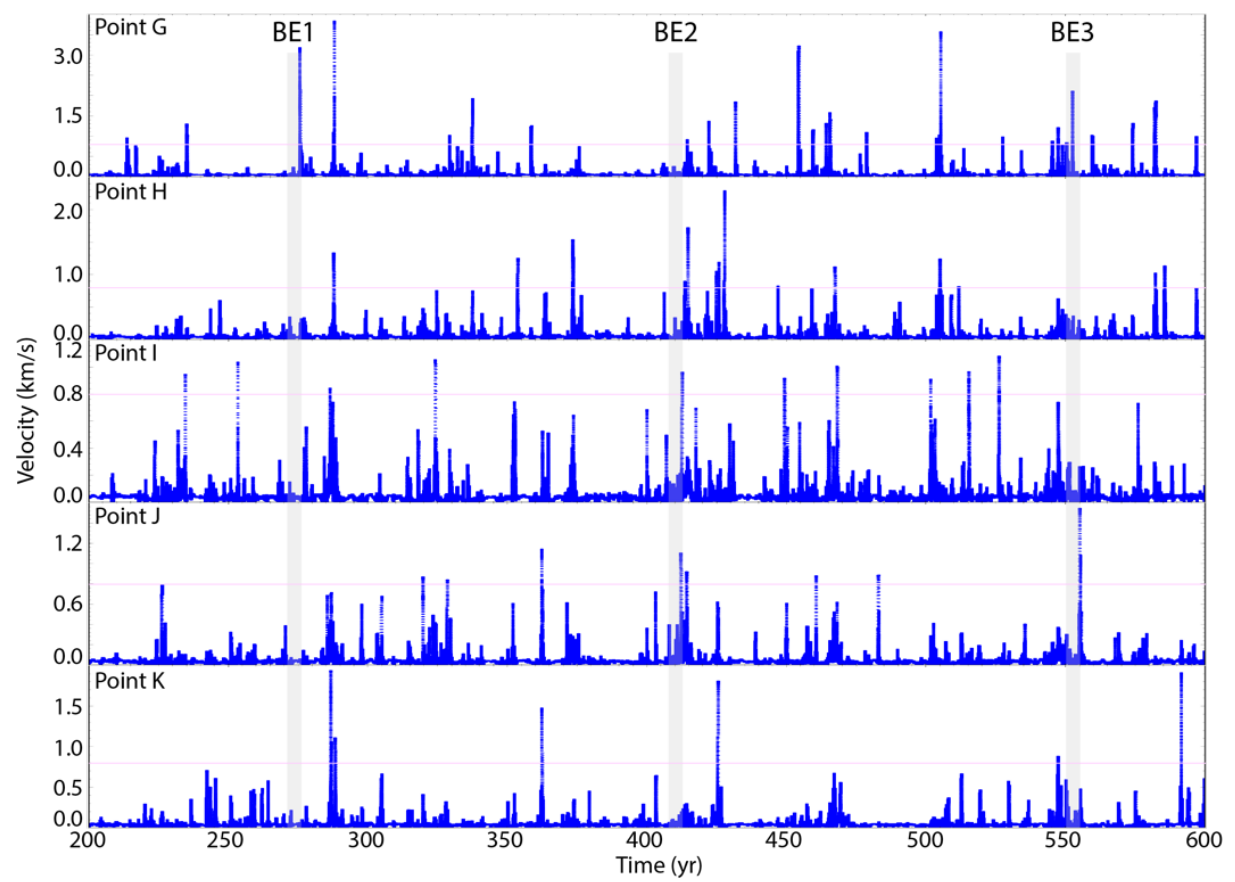

Figure 16: Instantaneous velocity spectrums of Point $G$ to $K$ close to the seamount along the slab during the modeled 400 years. Many small events can be identified. The big events BE1-3 (indicated by light gray bars) do not cause significant peaks in these spectrums. The horizontal light pink line corresponds to a velocity of $0.8 \mathrm{~km} / \mathrm{s}$, for reference. The key reference locations (Point $\mathrm{G}$ to $K$ ) are denoted in Fig. 6. 
https://doi.org/10.5194/se-2020-41

Preprint. Discussion started: 7 April 2020

(C) Author(s) 2020. CC BY 4.0 License.

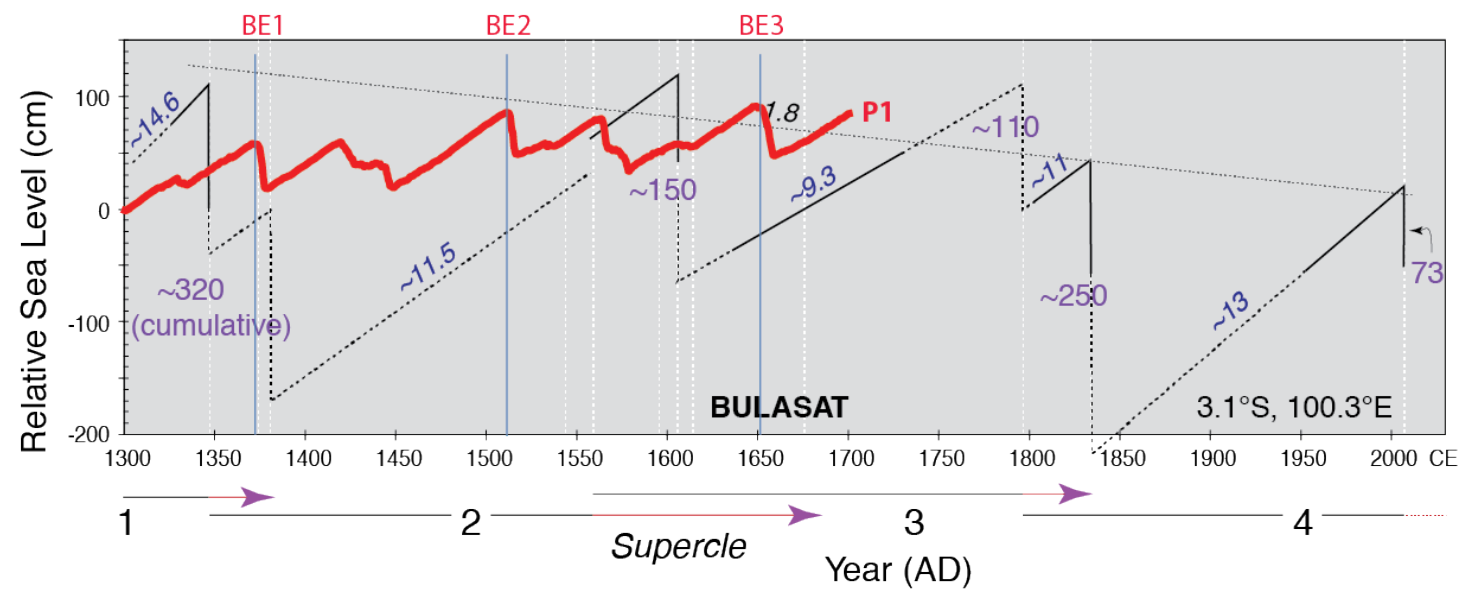

Figure 17: Comparison of the vertical motion of the point $P 1$ in the modeling and paleoseismic observations made in Bulasat in the

Mentawai area from Sieh et al. (2008). See more details in Fig. 1 and 8 above. 
https://doi.org/10.5194/se-2020-41

Preprint. Discussion started: 7 April 2020

(C) Author(s) 2020. CC BY 4.0 License.
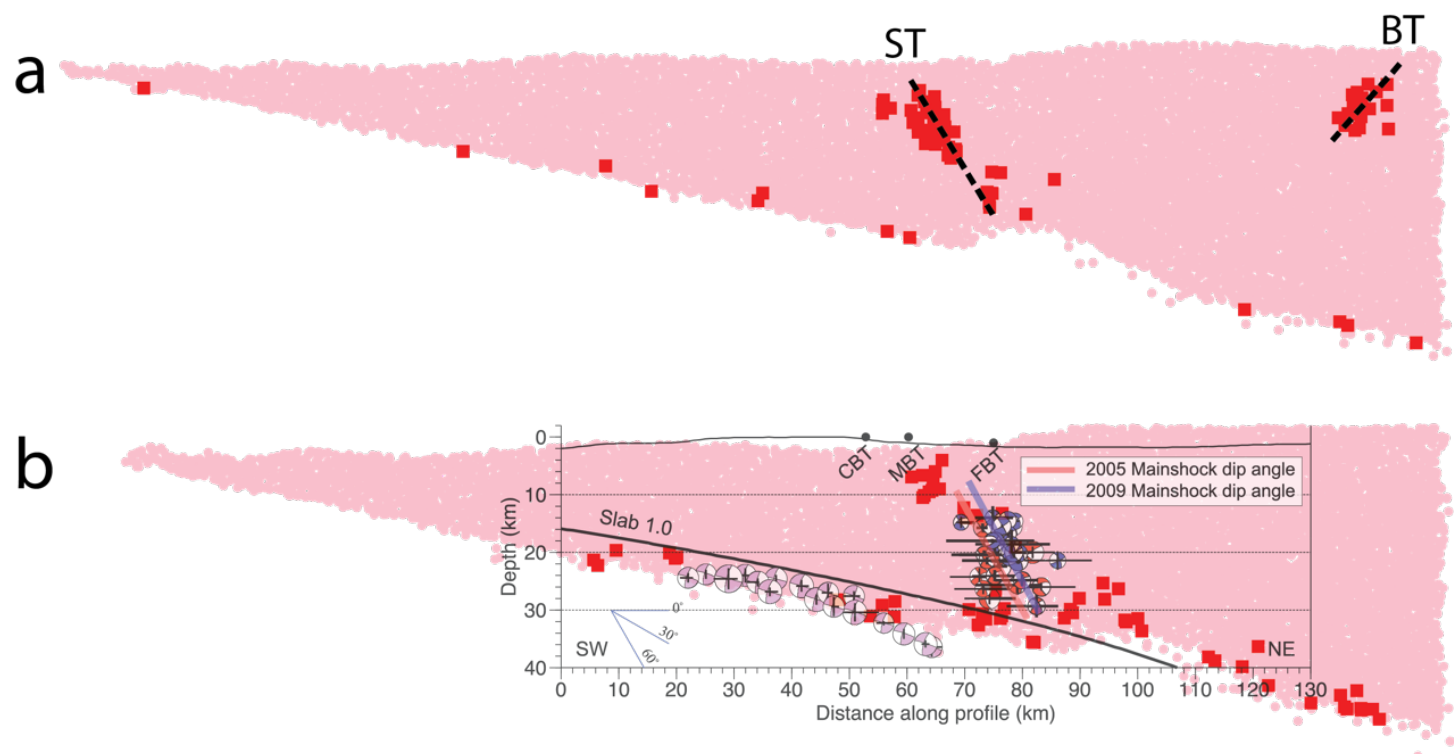

Figure 18: Crack swarms at (a) the beginning and (b) the end of the simulation period. The crack swarms are compared to the 855 seismic observations in (Wang et al., 2018). The locations and the dip angles of the slab and the splay fault (ST) are consistent with observations. 